\title{
Does Stock Listing Affect Value Creation and Profitability? Evidence from European Listed and Unlisted Companies
}

\author{
Carmelo Intrisano $^{1}$, Anna Paola Micheli ${ }^{1} \&$ Anna Maria Calce ${ }^{1}$ \\ ${ }^{1}$ University of Cassino and Southern Lazio, Cassino, Italy \\ Correspondence: Anna Maria Calce, University of Cassino and Southern Lazio, Cassino, Via Folcara snc, Italy. \\ E-mail: annamariacalce@unicas.it
}

Received: September 17, 2020

Accepted: October 17, $2020 \quad$ Online Published: October 28, 2020

doi:10.5539/ijef.v12n11p130

URL: https://doi.org/10.5539/ijef.v12n11p130

\begin{abstract}
In this paper we have studied the issue of whether the stock listing decision impacts firms' performance and value. In detail, we compared listed and unlisted companies located in countries belonging to the Stoxx Europe 600 in a 3-year time horizon (2015-2017). Companies are grouped in sector in order to ensure a greater comparability of data. As variable representative of performance we used the return on equity while for value creation we chosen the ROE-ke differential. Using the statistical t-test we ascertain the comparability of values. Results of our study demonstrated that unlisted companies have greater profitability and generate higher value than listed peers. In particular, given the significance level at $1 \%$ resulting from the t-test for the difference between the means, profitability and value created are higher for unlisted companies compared to the listed especially for the Thecnology, Telecommunication and Industrials sectors.
\end{abstract}

Keywords: stock listing, value creation, performance, cost of equity, listed companies, unlisted companies

\section{Introduction}

The analysis of the effects of the capital market on the performance of firms and the complexity involved in determining the value created by companies has always been characterized by uncertainty. Many studies found the central role of the capital market in economic growth, as it provides risk capital to businesses, allows for the diversification of risk, directs financial resources towards the most productive investments (Hamid, 2004). However, the results achieved by the companies are different depending on the performance of competitors and considering the sector to which companies belong.

Starting from this assumptions the paper aims to evaluate the effects of the capital market on firms performance and value comparing listed and unlisted companies. Research idea is: "Do listed companies produce greater value and are more profitable than unlisted comparables?".

Companies, especially if smaller, may encounter limits in accessing financial sources different from contributions of owners or self-financing (McLaney, 2009, Bates \& Hally, 1982; Hutchinson \& Ray, 1983; Keown et al., 1985; Caselli, 2003). Innovative SMEs have a financial need that is hard to reconcile with bank credit (Corigliano et al., 2001). Their development potential is difficult to assess, given the intangibility and uncertainty of the assets, mostly based on original production techniques and/or new products. Hence, the importance that risk capital and accessibility to the stock market have assumed for these companies, especially where the self-financing and, more generally, the equity endowment by the corporate structure are insufficient to support the competitive growth projects.

In this way, the listing on stock market can represent the solution to overcome these financial constraints, since it allows to raise financial resources from investors with greater propensity to risk. The listing, however, is a strategic decision, not only to finance new investments, but also to improve the capital structure and encourage generational turnover. Company, through the IPO, places on the market the shares representing the capital, according to the three different methods represented by (1) the Public Offer for Subscription, (2) the Public Offer for Sale and (3) the Public Offer for Sale and Subscription.

With the first method, company offers to the market new shares resulting from a capital increase: the operation allows for a new financial structure, given the resources contributed by the new shareholders that are added to the existing ones. 
With the Public Offer for Sale, shares owned by one or more shareholders are offered to the market. Sale should regard a part or all the shares held. This allows to expand the shareholder base and at the same time the old shareholders can liquidate their equity investments.

Finally, with the Public Offer for Sale and Subscription, both new shares deriving from the capital increase and old shares sold by the company's shareholders are placed. In this way the voting capital structure is remodeled and new liquidity is acquired for the company.

Among the three methods of offering, Public Offer for Subscription is more functional to support growth objectives, as it allows the company to have new resources in the form of risk capital improving the financial structure. All this, of course, requires that the IPO will be successful, with the subscription of all the shares offered to the market.

The success of the IPO, in turn, depends on a set of internal and external conditions which the company management must consider. The IPO is a complex process, which requires the evaluation of all the factors capable of influencing its outcome. In the Ernst \& Young survey, the variables of a quantitative and qualitative nature are indicated, distinguished by degree of relevance according to the order of choice by institutional investors, each of whom responded to the survey by indicating the first five variables considered most important.

The most important quantitative variable was the debt to equity ratio, which represents the majority of responses (63\%), followed by the EPS growth (59\%), the sales growth $(55 \%)$ and the ROE (55\%). The least relevant variables are those of operational management: ROA (12\%), ROI (26\%) and gross margins (35\%). Indeed, the most significant qualitative variable is the management credibility and experience $(90 \%)$, followed by the quality of corporate strategy and its execution (73\%), the brand strength and market position (59\%), the Operational effectiveness ( 54\%) and the corporate governance practices (44\%), while the less relevant qualitative variables are the quality of investor relations (8\%), IFRS/US GAAP accounting tracking record (13\%) and the ability to recruit and retain talented people (14\%).

\section{Literature Review}

Some evidence investigated the factors that can affect the outcome of the IPOs, relating them to macroeconomic variables.

Among these, the study of Meluzin, Zinecker and Lapinska (2014) which, on a sample of 218 Polish companies, considering as variables the growth rate of GDP, the reference interest rate, the growth rate of industrial production, the stock market indices and private equity investments, concluded that the most important variables for the growth of IPOs are, in order of importance, the growth rate of GDP and the return on stock market indices.

Ameer (2012), studying the link between macroeconomic quantities and IPOs on the Malaysian financial market, highlighted that the macroeconomic quantities most able to influence the IPOs success were the nominal interest rate, the industrial production and the returns of equity indices.

In any case, listing on a regulated market produces a series of advantages for companies, some of which linked to the possibility of growth, given the availability of funding instruments reserved for listed companies. In particular, external growth strategies are more implementable, because the value of company is updated in real time.

In general, listed companies are more suitable for achieving and maintaining conditions of financial equilibrium, also by diversifying the sources of financing.

With the listing, companies not only obtain an improvement in their credit standing which leads to lower interest rates and, therefore, to a reduction in the cost of capital, but they can also count on a significant improvement of its image, especially towards external stakeholders. The regulation on financial markets requires some transparency constraints that make companies more reliable and less risky than unlisted peers.

The listing determines positive effects for shareholders, such as the greater liquidity of their investment. The liquidity of the stock can facilitate generational turnover, where it allows the owner to place on the market the equity investment that he does not intend to transfer to his family.

Listing also entails disadvantages, mainly in terms of costs to access the listing and to remain in the market. The first are one-off costs, connected to the procedures, actions and formalities required to be part of the price list. Their extent depends on the time needed to complete the listing process, considering that the more protracted the process, the higher the costs to be sustained (for example the cost for advisor that grows in proportion to the time associated with its professional consultancy). It is also true that the duration of the listing process is influenced 
by the quality and intensity of the advice; but this, in turn, generally lead to greater onerousness. In short, there is a real trade off between quality and intensity of performance on the one hand and time to reach the listing on the other.

Obviously, all this depends on the procedures and skills already existing in the company: an efficient organizational structure, with qualified personnel and tested procedures, can make it possible to get to the listing using even modest professional services, which involve lower costs (Romano, 2012).

The amount of costs relating to the listing process also depends on the size and method of placement, which differ depending on whether the offer is aimed at the retail market or not and by reason of the intermediaries to be involved in the transaction.

In addition to the one-off costs, the listing determines recurring costs for staying on the list, such as the periodic fee to be paid to the Stock Exchange. For the Italian Stock Exchange, for example, their amount which differs according to the segment of market is calculated on a fixed basis for the first year of access to the market and in proportion to the volume traded starting from the second year.

Finally, the listing also determines indirect costs, mostly linked to the obligations necessary to ensure compliance with the requirements in terms of trasparency imposed by the permanence on the financial markets and connected to the redefinition of its organizational structure.

Therefore, depending on how the advantages and disadvantages are combined, listing can create or destroy value. Hence the uncertainty that recurs among researchers on the relationship between listing and value.

Some authors compared listed companies with unlisted ones by observing their differences in performance and valuation (Mayer \& Alexander, 1991; Rondi et al., 1994; Rijken et al., 1999; Carpenter \& Rondi, 2004; Berkovitch et al., 2004).

Mayer and Alexander (1991) compared the characteristics and performance of 544 British listed companies with those of 56 large unlisted peers in the 1980-1987 period, grouped by size and sector. Their investigation concludes that listed companies achieve higher growth rates, invest more and are more profitable.

Abbate and Sapio (2015) focus on the growth rates of asset revenues in their comparative analysis between a sample of companies listed on the English AIM, belonging to the manufacturing sector, and a sample of unlisted comparables, in the period 1997-2009. Their results show that the operating revenues and investments of listed companies grow faster than unlisted companies.

Conversely, Akguc, Choi, and Kim (2015), examining the financial performance of listed vs unlisted companies in the United Kingdom in the period 2003-2012, show that the performance of unlisted typically outperforms that of listed companies. Unlisted companies, thanks to their managerial flexibility, are operationally more efficient, show a long-term perspective as evidenced by the intensity of investments in R\&D, have a greater diffusion of controlling interests and show a higher operating profitability.

Schoubben and Van Hullen (2008) analyze the relationship between listing and performance drivers, in a sample of Belgian listed and unlisted companies for the period 1992-2003. The results show that competition, financial pressure and family ownership have a positive effect on the performance of listed companies and a negative effect on those of unlisted companies.

The study of Xiaoying Xie (2010), comparing for the period 1994-2005 the performances of 218 US listed and unlisted companies from the insurance sector, show that listed companies are no more performing than unlisted ones.

With regard to Italy, Rondi et al. (1994) investigate the differential behavior of listed and unlisted companies, concluding that the listed ones, even if they are less indebted given the greater availability of equity, are fewer profitable and make less fixed investments than the unlisted comparables.

The same conclusions reach Capasso et al. (2005) which, with reference to the period 1999-2003, compare the performances of two samples respectively of 30 listed companies and 30 unlisted companies grouped by size and sector. The Authors confirm that listed companies grow at a faster rate, employ less financial leverage, invest less in tangible assets, but have lower return on equity.

Similarly, Aiello and Silipo (1997), in their survey of 1,728 Italian companies, of which 71 listed, note a profitability differential in favor of unlisted companies: listed companies would show a lower cost of debt and greater production efficiency, however not so significant as to determine an equally superior profitability of capital. 
Other researchers analyze the relationship between listing and value by investigating performance before and after listing.

Mikkelson et al. (1997), analyzing 283 IPOs in the US in the period 1980-1983, highlight that operating and company performance is below average after listing. The Authors found that after the listing the performance deteriorates when compared with the pre-listing level, given the operating profitability which falls from $9 \%$ to $2 \%$.

Nguyen and Trinh (2019) also investigate the performance of companies pre and post listing, on a panel of 48 Vietnamese companies, in the period 2005-2007. Results show that the listing on the stock market is not accompanied by an improvement in company performance: in the post-listing period, although the listing improves sales, there is neither an increase in profitability nor an improvement in operational efficiency.

With reference to an extended sample of Italian IPOs, Pagano et al. (1998) observe a strong and permanent decline in capital expenditures in the post-listing period, to be ascribed to the investment plans prepared with a view to listing, given the preference of unlisted companies for investments in tangible assets. The results of their study also state that return on equity is better in pre-listing companies.

\section{Methodology}

Value, as a synonym of utility, is not an absolute concept but has a relative dimension, since it implies the specification of the subject to which to refer. Firms create value on the basis of the benefits they are able to produce for shareholders, net of the sacrifices. Benefits and sacrifices are represented respectively by profitability and the cost of capital.

Two approaches can be distinguished (Zamagni, 2006); the former, called stakeholders approach, considers value creation for all lenders whether they have contributed debt or equity. The second is the shareholders approach and considers value creation to be reported exclusively to the shareholders/owners. The different configurations of value mean that the explanatory variables are also different in the two approaches. In the stakeholder approach the explanatory variables of the benefits and sacrifices are generally the return on invested capital (ROI) and the weighted average cost of capital (WACC). In the shareholder approach variables are represented by the return on equity (ROE) and the cost of equity (ke).

In this way, the following analysis is conducted using the shareholder approach which is prevalent in literature given the widely shared opinion that the true purpose of the company is to achieve and satisfy the expectations of the owners. This implies that the notion of value we consider is that of value for shareholders.

The investigated value, therefore, is the combination of the results achieved in terms of profitability and business risk. ROE, in fact, does not have its own reporting capacity: an increase in company profitability, for example, can underlie a destruction rather than a creation of value if the growth in ROE is obtained by worsening the risk profile of the company; in the same way, a decrease in ROE can imply a creation rather than a destruction of value, if it is to be connected to business risk containment interventions.

As stated above, this study aims to answer to the question: "Do listed companies produce greater value and are more profitable than unlisted comparables?". The work consists in the differential analysis of the profitability and of the value produced by listed companies compared with the same measures referred to unlisted peers. The methodological approach is common with other empirical evidence, from which, however, it differs, since it isolates the variations recorded over time from the performance and attributable to the sector to which companies belong, using separate survey samples for the different sectors: this last are affected and react in different ways to the economic situation. So, cyclical firms amplify market trends while non-cyclical firms show greater stability over time. It follows that the surveyed companies could show a differential value, since they belong to different sectors and not because of their listed/unlisted status.

The empirical investigation regards the following areas:

- differential analysis of the profitability (ROE) of listed companies vs unlisted companies;

- differential analysis of the value (ROE-ke) of listed companies vs unlisted companies.

Listed and unlisted companies were extracted from the Amadeus database and grouped into nine samples, corresponding to the Healthcare, Consumer cyclical, Consumer non-cyclical, Energy, Industrials, Basic Materials, Technology, Telecommunications and Utilities sectors. Furthermore, given the low number of listed companies by sector, we considered companies from several European countries and, in particular, those included in the Stoxx Europe 600 (Austria, Belgium, Czech Republic, Denmark, Finland, France, Germany, England, Ireland, Italy, Luxembourg, Holland; Norway, Portugal, Sweden, Switzerland and Spain), assuming that share the same 
equity index implies elements of affinity between countries themselves.

Analysis refers to the period 2015-2017. There were 861878 companies, of which 4209 listed and 857669 unlisted. The series of data were subjected to the elimination of the outliers, to improve the normality of the relative distributions. The final composition of the two samples is: for 2015 n. 393678 companies, of which 2593 listed; for 2016 n. 411902 companies, of which 2694 listed; for 2017 n. 260 178, of which 2763 are listed.

We computed the period and sector means values and then the difference between the means for both ROE and ROE-ke.

The estimate of the variable representing the value (i.e. ROE-ke) required the preliminary quantification of the cost of equity (ke). This can be considered as an opportunity cost, representative of the sacrifices that the shareholder sustains having renounced the return that he could have made if he had invested in other activities with the same degree of risk.

Cost of equity is directly correlated to the risk of the company which, in turn, depends on various factors, some of which connected to the going public decision. Listed companies imply a lower risk for the shareholder, since they must meet specific transparency and control requirements for admission and permanence in the market.

However, these obligations entail the bureaucratization of decision-making processes which, in turn, produces an additional rigidity and a lesser capacity to adapt to variable market conditions.

We calculated the average values for $\mathrm{k}_{\mathrm{e}}$, for all sectors, years and status listed/unlisted.

First of all the unlevered cost of equity values $\left(k_{e_{u_{s}}}\right)$ for the various sectors were quantified on the basis of the financial structure $(D / E)_{s}$ and the corresponding levered values $\left(k_{e_{l_{s}}}\right)$ of each sector. The latter were estimated by calculating the average of the $k_{e_{l_{s}}}$ at the beginning, intermediate and end of the period, taking as reference the values determined by the researchers of the Value Trust, using Babbel's Residual Income Valuation Model (Note 1, 2).

In particular the average values of $k_{e_{l_{s}}}$ for each sector were transformed into correspondents $k_{e_{u_{s}}}$, canceling the effect determined by the financial structure on the cost of equity, being:

$$
k_{e_{u_{s}}}=\frac{k_{e_{l_{s}}}+r_{f} \times(D / E)_{s}}{1+(D / E)_{s}}
$$

Consistently with $\mathrm{k}_{\mathrm{e}_{\mathrm{s}}}$, the risk free rate $r_{f}$, for each year of the period under investigation 2015-2017, is obtained by calculating the average of the values of the beginning, intermediate and end of the period, taking as a reference the values by the researchers of Value Trust. These are determined starting from the long-term government bonds of European countries with the highest rating, ie Germany, Luxembourg and the Netherlands, and then estimate, using the Svensson method, the yield curve, the relative zero coupon up to 30 years.

Table 1. Risk free rate (2015-2017)

\begin{tabular}{ccc}
\hline $\mathbf{2 0 1 5}$ & $\mathbf{2 0 1 6}$ & $\mathbf{2 0 1 7}$ \\
\hline $1.52 \%$ & $1.16 \%$ & $1.17 \%$ \\
\hline
\end{tabular}

Source: elaboration on Value Trust data.

Table 2. $\mathrm{k}_{\mathrm{e}_{\mathrm{u}_{\mathrm{s}}}}$ sectors (2015-2017)

\begin{tabular}{llll}
\hline \multicolumn{1}{c}{ Sectors } & $\mathbf{2 0 1 5}$ & $\mathbf{2 0 1 6}$ & $\mathbf{2 0 1 7}$ \\
\hline Health care & $4.55 \%$ & $4.55 \%$ & $4.61 \%$ \\
Consumer cyclical & $4.62 \%$ & $4.40 \%$ & $4.60 \%$ \\
Consumer non-cyclical & $4.27 \%$ & $3.93 \%$ & $4.49 \%$ \\
Energy & $3.95 \%$ & $3.15 \%$ & $3.40 \%$ \\
Basic materials & $4.34 \%$ & $4.09 \%$ & $4.09 \%$ \\
Industrials & $5.18 \%$ & $4.88 \%$ & $5.07 \%$ \\
Technology & $4.25 \%$ & $3.98 \%$ & $4.47 \%$ \\
Telecommunications & $3.47 \%$ & $3.32 \%$ & $3.73 \%$ \\
Utility & $3.38 \%$ & $3.03 \%$ & $3.03 \%$ \\
\hline
\end{tabular}


Once determined $k_{e_{u_{s}}}$ for sectors, for each listed/unlisted company the relative $k_{e_{l_{i}}}$ is calculated give the relation:

$$
k_{e_{i}}=k_{e_{u_{s}}}+\left(k_{e_{u_{s}}}-r_{f}\right) \times(D / E)_{i}
$$

where $\mathrm{k}_{\mathrm{e}_{\mathrm{i}}}$ and $(D / E)_{i}$ are respectively the levered cost of equity and the financial structure of the $\mathrm{i}^{\text {th }}$ company. The average values of $\mathrm{k}_{\mathrm{e}_{1}}$ by sector were calculated. They are summarized in the following table:

Table 3. $k_{e_{l}}$ (average values) for sectors (2015-2017)

\begin{tabular}{|c|c|c|c|c|c|c|c|c|}
\hline \multirow{2}{*}{ Sectors } & \multicolumn{2}{|c|}{2015} & \multicolumn{2}{|c|}{2016} & \multicolumn{2}{|c|}{2017} & \multicolumn{2}{|c|}{ 2015-2017 } \\
\hline & Listed & Unlisted & Listed & Unlisted & Listed & Unlisted & Listed & Unlisted \\
\hline Health care & $7.47 \%$ & $7.51 \%$ & $7.93 \%$ & $7.82 \%$ & $7.80 \%$ & $7.76 \%$ & $7.72 \%$ & $7.70 \%$ \\
\hline Consumer cyclical & $8.14 \%$ & $9.57 \%$ & $7.71 \%$ & $10.40 \%$ & $8.17 \%$ & $10.06 \%$ & $8.01 \%$ & $10.01 \%$ \\
\hline Consumer non-cyclical & $6.76 \%$ & $8.56 \%$ & $6.50 \%$ & $8.24 \%$ & $7.42 \%$ & $9.60 \%$ & $6.89 \%$ & $8.80 \%$ \\
\hline Energy & $8.85 \%$ & $11.51 \%$ & $6.67 \%$ & $8.85 \%$ & $7.58 \%$ & $9.35 \%$ & $7.70 \%$ & $9.90 \%$ \\
\hline Basic Materials & $7.71 \%$ & $8.79 \%$ & $7.67 \%$ & $8.71 \%$ & $7.57 \%$ & $8.44 \%$ & $7.65 \%$ & $8.67 \%$ \\
\hline Industrial & $7.53 \%$ & $10.17 \%$ & $7.31 \%$ & $9.88 \%$ & $7.71 \%$ & $10.34 \%$ & $7.52 \%$ & $10.13 \%$ \\
\hline Technology & $6.63 \%$ & $8.66 \%$ & $6.73 \%$ & $8.39 \%$ & $7.54 \%$ & $9.53 \%$ & $7.00 \%$ & $8.86 \%$ \\
\hline Telecommunications & $6.44 \%$ & $6.45 \%$ & $6.21 \%$ & $6.70 \%$ & $7.12 \%$ & $7.75 \%$ & $6.59 \%$ & $6.97 \%$ \\
\hline Utility & $6.11 \%$ & $5.87 \%$ & $6.23 \%$ & $5.93 \%$ & $6.55 \%$ & $7.17 \%$ & $6.28 \%$ & $6.24 \%$ \\
\hline
\end{tabular}

We compared profitability in listed and unlisted companies using the means value of ROE (computed as Net Income/ Shareholder's Equity) while for the value creation comparison we refered to the means value of ROE-ke. Then, we computed differences between the means of both variables in order to establish if means value of the two samples are really comparable. In this way, differences between the means were subjected to t-test to ascertain its statistical significance. The research's hypothesis we wanted to test is the greater ability of listed companies to create value and be more profitable than unlisted compables. Operationally, this should correspond to obtaining higher average values of the ROE and ROE-ke for listed companies than for unlisted ones.

\section{Results}

\subsection{Differential Analysis of Profitability (ROE)}

The shareholder value approach, adopted in this paper, should lead to calculating the differential value of the listing considering dividends and capital gain, as they are representative of the economic benefit for shareholders.

However, dividends have the limit of being subject to pay out and, more generally, to the dividend policy, often defined by management regardless of the actual creation of value: for example, the decision to distribute dividends may originate from the need to use liquidity in excess, in the absence of investment opportunities with positive NPV, or it can derive from the desire to provide a signal to the market, supporting the share price.

In the same way, the capital gain discounts the limit of inapplicability in unlisted companies which, unlike listed companies, do not have their own market price.

On the contrary, the return on equity expressed by the ROE is not affected by these limits and represents an adequate proxy of the value created by the company for the shareholders, as it is explanatory of the benefits deriving from the investment decision. However, this is a gross value, from which sacrifices faced by the shareholder must be subtracted, in terms of the opportunity cost of capital, corresponding to the return he could have achieved if he had decided to invest in other assets with the same risk profile.

In any case, ROE is the result of both the value generated by operations and expressed by the return on invested capital (ROI) and the effects deriving from the financial structure. Given a financial need, the increase in debt, in fact, produces a positive leverage effect on the ROE as long as the profitability of the invested capital is higher than the cost of debt (i) and, conversely, a negative leverage effect when the ROI is lower than $\mathrm{i}$.

Nonetheless, operating profitability is affected by the implications that the economic situation has on the business carried out by the company: in periods of expansion / recession, for example, cyclical sectors tend to outperform / underperform compared to non-cyclical sectors which instead show greater stability. Basically, the profitability of the company is also attributable to the trend of the sector to which it belongs. 
In light of this, in this survey, in order to measure the effects produced by the listing on the ROE, by isolating the variations in profitability attributable to the sector and not already from the listing, we proceeded with the differential analysis of listed and unlisted companies belonging to the same sector.

With this methodological approach, therefore, the average values of the ROE were calculated, separately by sector, year and by status listed / unlisted.

Table 4. ROE (average values): listed vs unlisted companies

\begin{tabular}{lcccccccc}
\hline \multirow{2}{*}{ Sectors } & \multicolumn{2}{c}{$\mathbf{2 0 1 5}$} & \multicolumn{2}{c}{$\mathbf{2 0 1 6}$} & \multicolumn{2}{c}{$\mathbf{2 0 1 7}$} & $\mathbf{2 0 1 5 - 2 0 1 7}$ \\
\cline { 2 - 8 } & Listed & Unlisted & Listed & Unlisted & Listed & Unlisted & Listed & Unlisted \\
\hline Health care & $-9.18 \%$ & $11.51 \%$ & $5.90 \%$ & $11.75 \%$ & $2.70 \%$ & $11.59 \%$ & $-0.73 \%$ & $11.62 \%$ \\
Consumer cyclical & $9.27 \%$ & $6.78 \%$ & $9.14 \%$ & $7.47 \%$ & $8.75 \%$ & $21.57 \%$ & $9.05 \%$ & $8.22 \%$ \\
Consumer non-cyclical & $1.08 \%$ & $12.40 \%$ & $3.24 \%$ & $12.50 \%$ & $-0.81 \%$ & $12.42 \%$ & $1.17 \%$ & $12.44 \%$ \\
Energy & $2.07 \%$ & $9.97 \%$ & $5.03 \%$ & $9.31 \%$ & $0.43 \%$ & $10.96 \%$ & $2.41 \%$ & $10.08 \%$ \\
Industrials & $9.12 \%$ & $14.48 \%$ & $9.03 \%$ & $14.80 \%$ & $9.13 \%$ & $14.23 \%$ & $9.09 \%$ & $14.53 \%$ \\
Basic Materials & $-2.48 \%$ & $9.41 \%$ & $-0.04 \%$ & $10.02 \%$ & $1.68 \%$ & $10.16 \%$ & $-0.23 \%$ & $9.86 \%$ \\
Technology & $7.16 \%$ & $21.76 \%$ & $8.53 \%$ & $21.93 \%$ & $3.91 \%$ & $21.90 \%$ & $6.41 \%$ & $21.86 \%$ \\
Telecommunications & $3.71 \%$ & $15.11 \%$ & $8.71 \%$ & $15.09 \%$ & $7.09 \%$ & $15.45 \%$ & $6.57 \%$ & $15.22 \%$ \\
Utility & $-1.22 \%$ & $7.19 \%$ & $7.07 \%$ & $9.54 \%$ & $7.22 \%$ & $9.55 \%$ & $4.11 \%$ & $8.75 \%$ \\
\hline
\end{tabular}

With reference to the entire 2015-2017 period and to the listed companies, the sectors that record the best ROE values are: Industrials (9.09\%), Consumer cyclical (9.05\%) and Telecommunications $(6.57 \%)$; on the contrary, the sectors with the worst values are Consumer non-cyclical (1.17\%), Basic materials $(-0.23 \%)$ and Healthcare $(-0.73 \%)$. For the unlisted, the first three sectors are, in order of importance of ROE, Technology (21.86\%), Telecommunications (15.22\%) and Industrials (14.53\%), while the last sectors are Basic materials (9.86\%), Utility $(8.75 \%)$ and Consumer cyclical (8.22\%). It should be noted that unlike the listed ones, no sector shows an average negative ROE for the period.

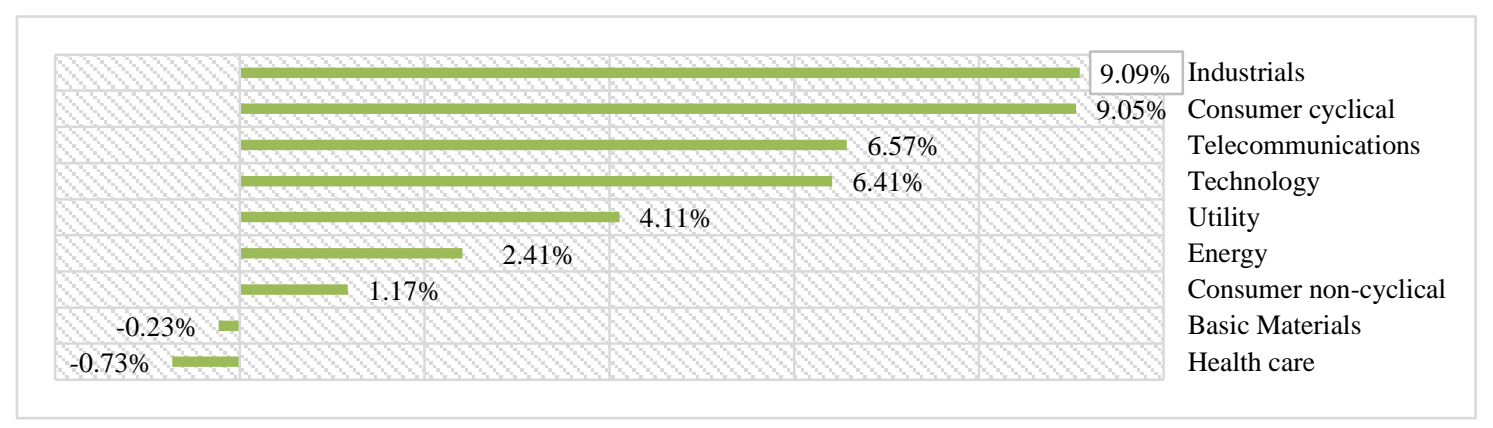

Figure 1. ROE (average values): ranking listed companies (2015-2017)

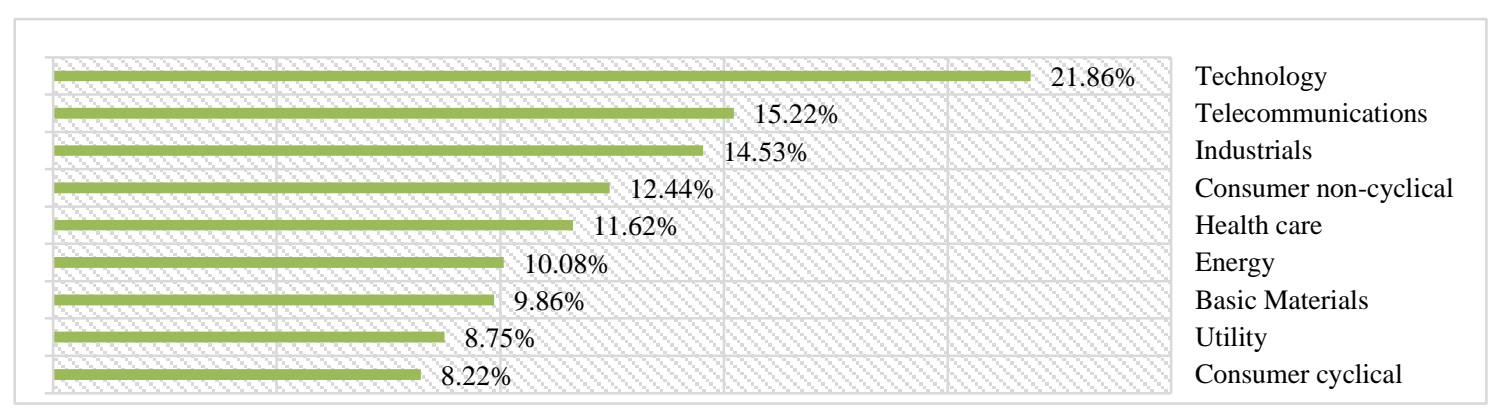

Figure 2. ROE (average values): ranking unlisted companies (2015-2017)

With regard to individual years, for 2015 it is noted that the highest ROE values of listed companies are associated with the Consumer cyclical (9.27\%), Industrials (9.12\%) and Technology (7.16\%) sectors while the lowest values are in the Utility (-1.22\%), Basic Materials (-2.48\%) and Healthcare (9.18\%) sectors. For the 
unlisted, Technology (21.76\%), Telecommunications (15.11\%) and Industrial (14.48\%) record the first values of ROE, vice versa Basic materials (9.41\%) Utilities (7.19\%) and Consumer cyclical (6.78\%) show the latest values. Also for the year 2015, it should be noted that the ROE of unlisted companies is positive for all sectors, contrary to listed companies, whose ROE assumes negative values even for three sectors.

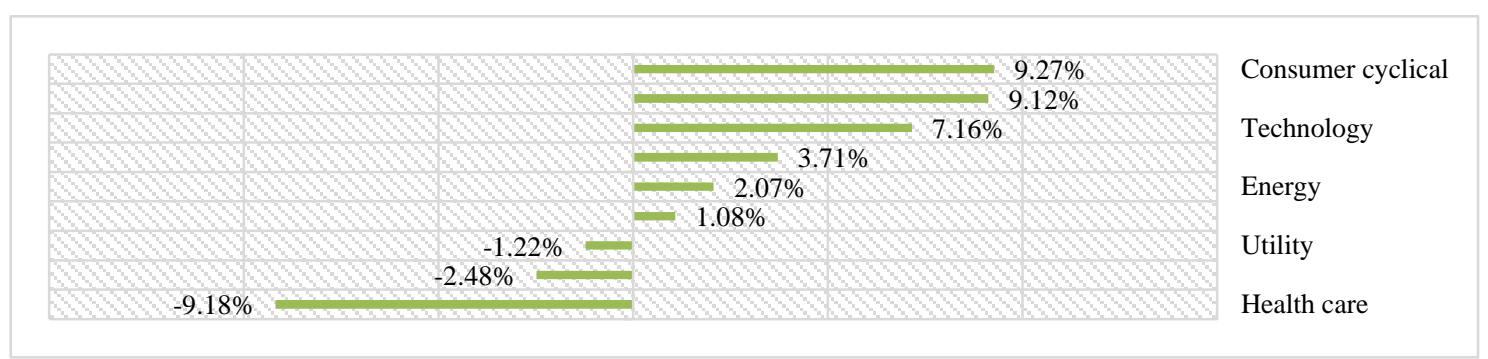

Figure 3. ROE (average value): ranking listed companies (2015)

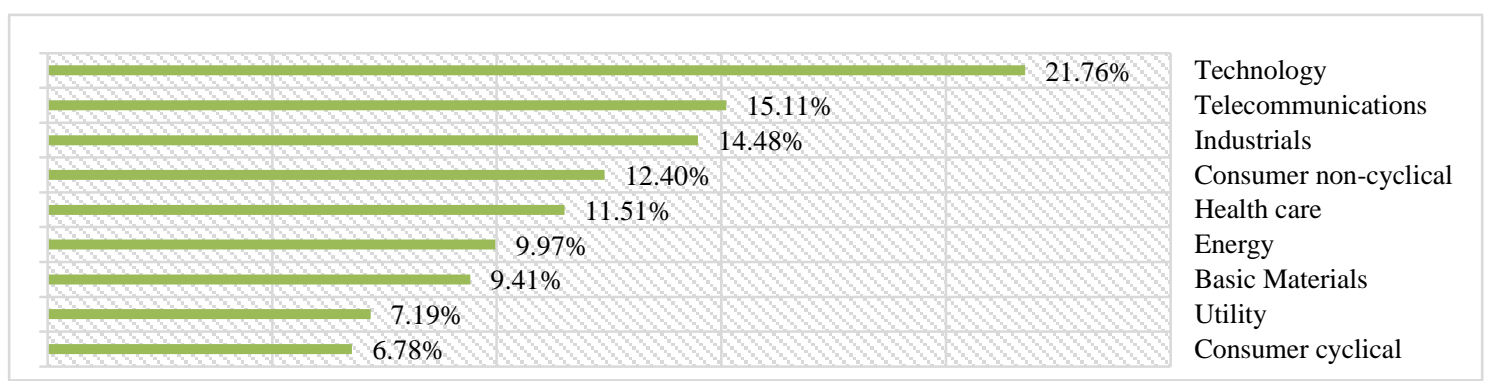

Figure 4. ROE (average values): ranking unlisted companies (2015)

For 2016, the highest ROE values of the listed companies are in the Consumer cyclical (9.14\%), Industrials (9.03\%) and Telecommunications $(8.71 \%)$ sectors; on the other hand, the lowest values are in the Energy $(5.03 \%)$, Consumer non-cyclical $(3.24 \%)$ and Basic Materials (-0.04\%) sectors. For the unlisted, the first three values of ROE are represented by the Technology $(21.93 \%)$, Telecommunications $(15.09 \%)$ and Industrials $(14.80 \%)$ sectors, on the contrary the last three values correspond to the Healthcare sectors $(5.90 \%)$, Energy $(9.31 \%)$ and Consumer cyclical $(7.47 \%)$.

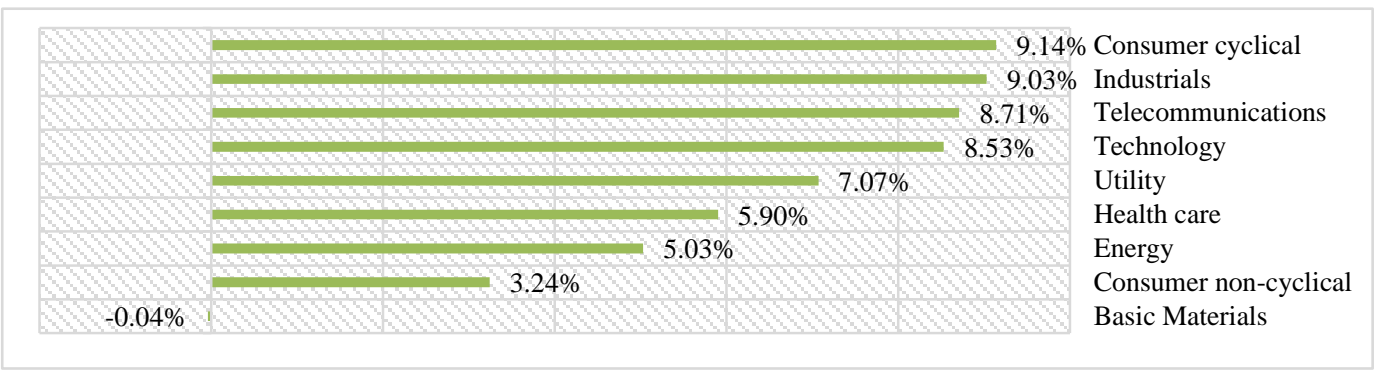

Figure 5. ROE (average values): ranking listed companies (2016)

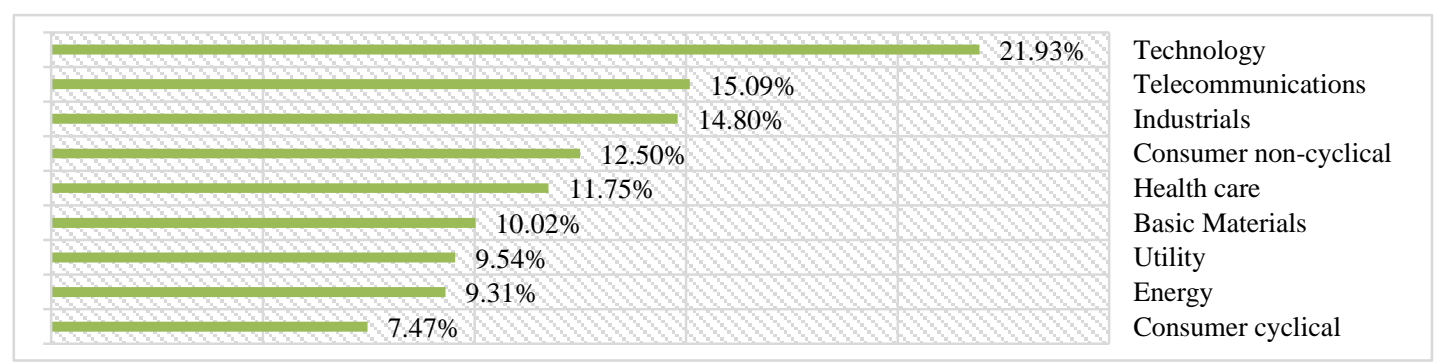

Figure 6. ROE (average values): ranking unlisted companies (2016) 
Finally, for 2017, the listed companies with the highest ROE values belong to the Industrials (9.13\%), Consumer cyclical $(8.75 \%)$ and Utility $(7.22 \%)$ sectors while the worst values are related to the Consumer non-cyclical $(-0.81 \%)$, Energy $(0.43 \%)$ and Basic materials $(1.68 \%)$. For the unlisted sectors, the sectors with the highest ROE values are Technology (21.90\%), Consumer cyclical (21.57\%) and Telecommunications (15.45\%), while the sectors with the lowest values are Utilities (9.55 \%), Basic materials (10.16\%) and Energy (10.96\%).

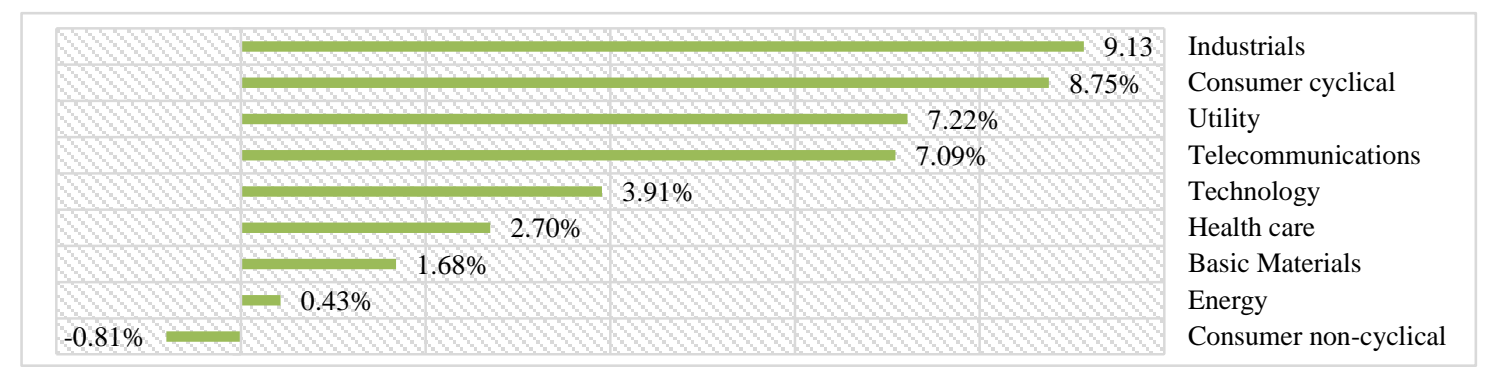

Figure 7. ROE (average values): ranking listed companies (2017)

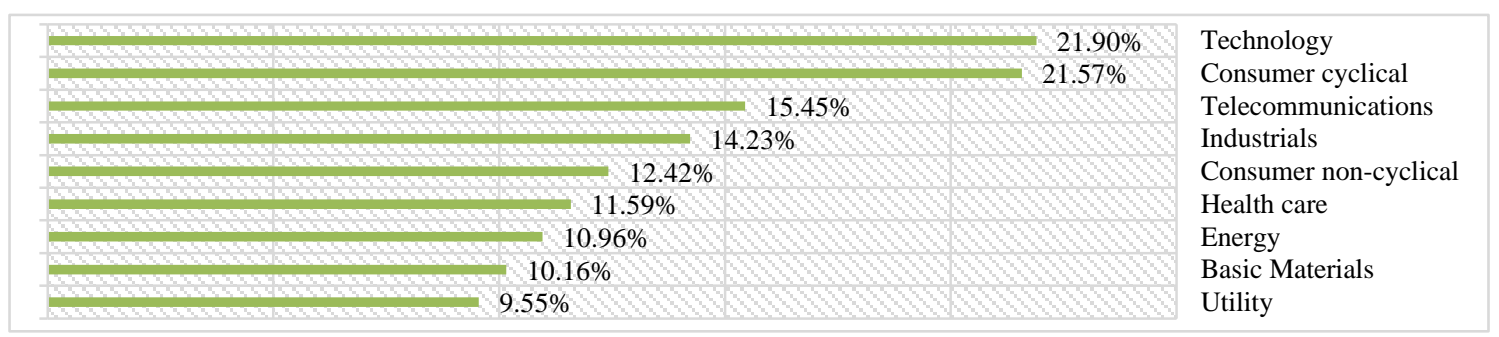

Figure 8. ROE (average values): ranking unlisted companies (2017)

The intensity of the differences in ROE, recorded between listed companies and unlisted companies, assumes more importance, for the purpose of explaining the effects produced by the listing on profitability, if the differences are significant and common to the various sectors. Considering this, in the present work the differences between the means for ROE were calculated and the statistical significance was verified by the t-test. Results of the statistic test showed that the difference between the means of the listed and unlisted are comparable, given the $1 \%$ level of significance for all sectors and years.

Table 5. ROE: difference between the means listed vs unlisted companies

\begin{tabular}{lllll}
\hline Sectors & 2015 & 2016 & 2017 & $2015-2017$ \\
\hline \multirow{2}{*}{ Health care } & $-20.69 \% * * *$ & $-5.85 \% * * *$ & $-8.89 \% * * *$ & $-12.35 \% * * *$ \\
Consumer cyclical & $(0.003)$ & $(0.006)$ & $(0.000)$ & $(0.000)$ \\
& $2.49 \% * * *$ & $1.67 \% * * *$ & $-12.82 \% * * *$ & $0.83 \% * * *$ \\
Consumer non-cyclical & $(0.000)$ & $(0.000)$ & $(0.000)$ & $(0.006)$ \\
& $-11.32 \% * * *$ & $-9.26 \% * * *$ & $-13.23 \% * * *$ & $-11.27 \% * * *$ \\
Energy & $(0.000)$ & $(0.000)$ & $(0.000)$ & $(0.000)$ \\
& $-7.90 \% * * *$ & $-4.28 \% * * *$ & $-10.53 \% * * *$ & $-7.67 \% * * *$ \\
Industrials & $(0.002)$ & $(0.009)$ & $(0.002)$ & $(0.000)$ \\
& $-5.36 \% * * *$ & $-5.77 \% * * *$ & $-5.10 \% * * *$ & $-5.44 \% * * *$ \\
Basic Materials & $(0.000)$ & $(0.000)$ & $(0.000)$ & $(0.000)$ \\
Technology & $-11.89 \% * * *$ & $-10.06 \% * * *$ & $-8.48 \% * * *$ & $-10.09 \% * * *$ \\
& $(0.000)$ & $(0.000)$ & $(0.000)$ & $(0.000)$ \\
Telecommunications & $-14.60 \% * * *$ & $-13.40 \% * * *$ & $-17.99 \% * * *$ & $-15.45 \% * * *$ \\
& $(0.000)$ & $(0.000)$ & $(0.000)$ & $(0.000)$ \\
Utility & $-11.40 \% * * *$ & $-6.38 \% * * *$ & $-8.36 \% * * *$ & $-8.65 \% * * *$ \\
\hline
\end{tabular}

Note. Level of significance $* 10 \%, * * 5 \%, * * * 1 \%$. 
With reference to the entire 2015-2017 period, negative differences emerge for all sectors, demonstrating that the profitability of the unlisted is always greater than the profitability of the listed ones. In particular, this superiority is more marked in the sectors of Technology $(-15.45 \%)$, Healthcare $(-12.35 \%)$ Consumer non-cyclical (-11.27\%) and less significant in Consumer cyclical (0.83\%), Utilities (-4.64\%) and Industrials (-5.44\%).

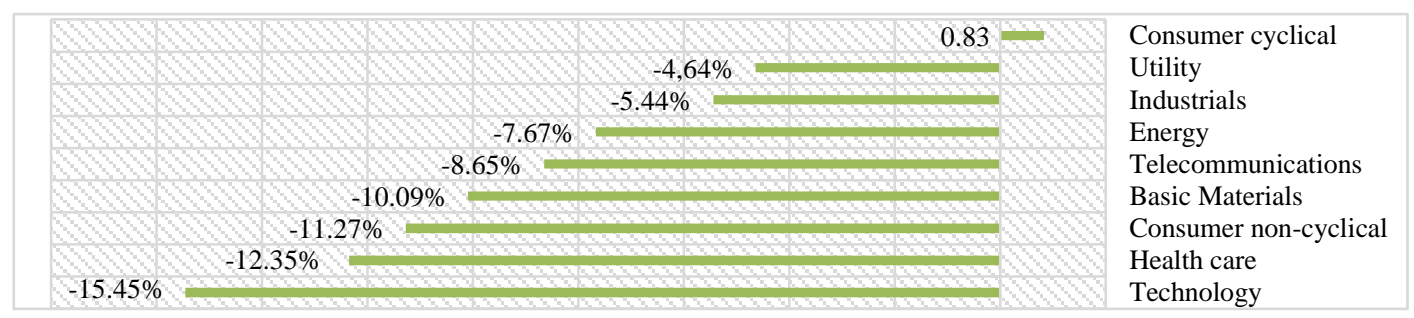

Figure 9. ROE: ranking difference between the means listed vs unlisted companies (2015-2017)

With regard to the individual years, 2015 substantially confirmed the higher profitability of unlisted companies in all sectors with the exception of Consumer cyclical, which showed a positive differential in favor of listed companies. The sectors in which the profitability gap is most significant are Healthcare (-20.69\%), Technology $(-14.60 \%)$ and Basic Materials (-11.89\%).

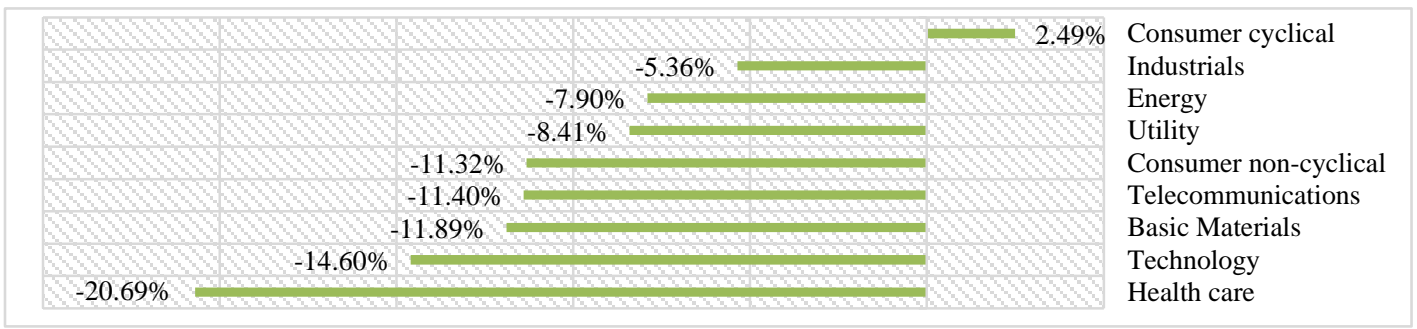

Figure 10. ROE: ranking difference between the means listed vs unlisted companies (2015)

Also for 2016, the clear superiority of unlisted companies emerges, whose ROE is higher than those recorded for listed peers in all sectors, again with the sole exception of the Consumer cyclical sector which presents an additional profitability of $1.67 \%$ in favor of listed. The sectors with the most significant differences are Technology (-13.40\%), Basic materials (-10.06\%) and Consumer non-cyclical (-9.26\%).

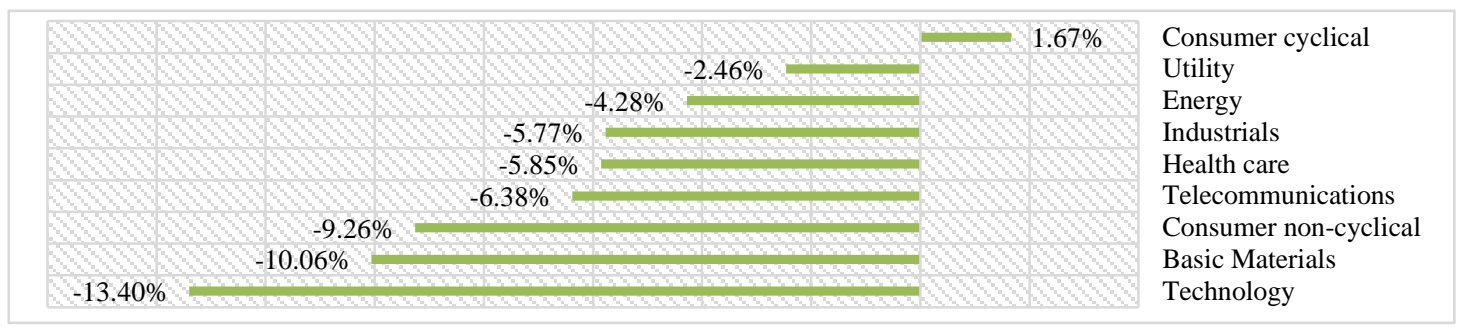

Figure 11. ROE: ranking difference between the means listed vs unlisted companies (2016)

Similarly, for 2017 the profitability of unlisted companies is higher than those listed in all sectors, particularly in the Technology (-17.99\%), Consumer non-cyclical (-13.23\%) and Consumer cyclical (-12, 82\%).

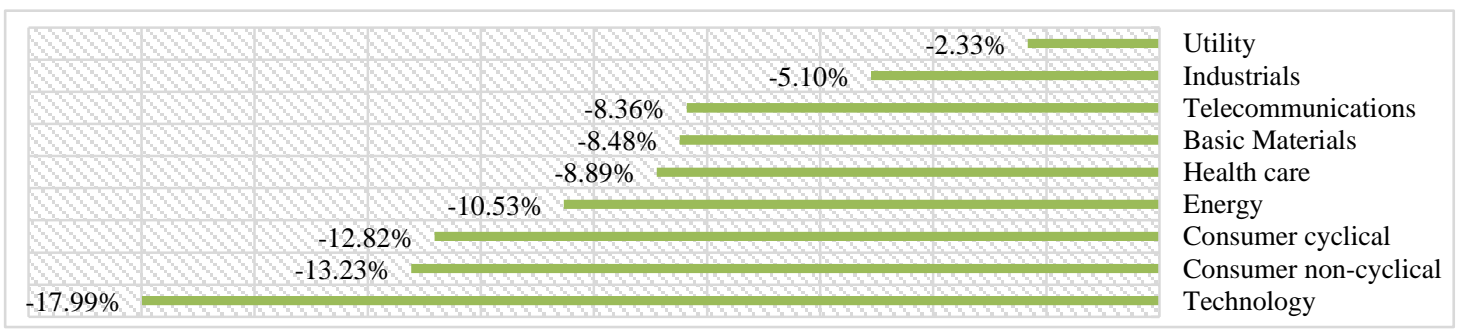

Figure 12. ROE: ranking difference between the means listed vs unlisted companies (2017) 
At this point of the investigation, in order to verify whether the listing implies effects on profitability respect to market trends, the changes in ROE over the period were analyzed.

In fact, listed companies are characterized by slower decision-making processes which protect the interests of minority shareholders but can affect the profitability of the entire share capital, where, in the presence of unfavorable circumstances, they do not allow the company to take the most appropriate management decisions in a timely manner, given the changed context conditions. Basically, the listing, involving greater management rigidity and greater bureaucracy, would make profitability more unstable. It is the so-called "Bureaucratization effect" that the company would suffer with the listing, as claimed by part of the doctrine. The choices, especially those of a strategic nature, would be subject to a more complex, careful, formalized and rigid decision-making process than is normally the case in unlisted companies, where decisions are faster. This would be ascribable to the constraints envisaged for listed companies, mainly aimed at protecting minority shareholders and the market in general (Onesti et al, 2012).

To confirm this, we analyzed the profitability trend in the 2015-2017 period, separately for listed and unlisted companies, considering that the real GDP of the EU area grew by $2.3 \%$ in 2015, by $2.0 \%$ in 2016 and $2.5 \%$ in 2017.

In the Healthcare sector, ROE remains almost unchanged in unlisted companies $(11.51 \%$ in $2015,11.75 \%$ in 2016 and $11.59 \%$ in 2017) while in listed companies it improved significantly between $2015(-9.18 \%)$ and 2016 $(5.90 \%)$ and then decrease in the following year $(2.70 \%)$.

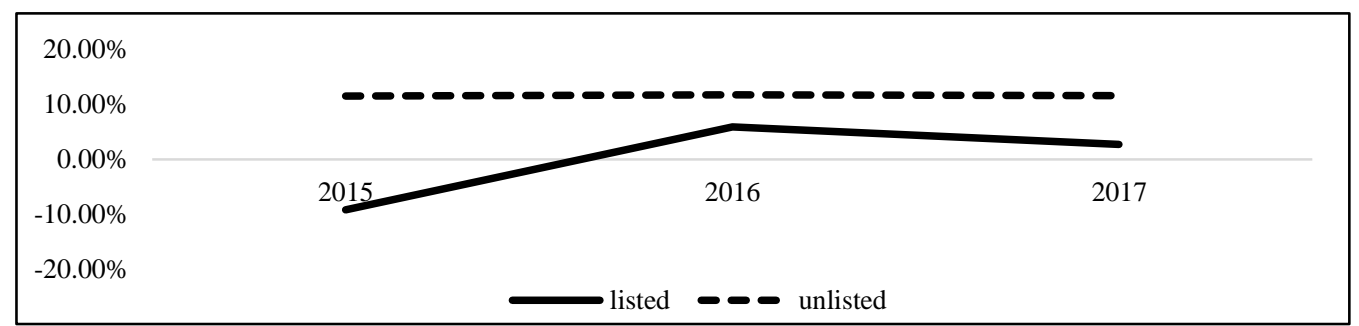

Figure 13. Health care: trend ROE (average values) listed vs unlisted companies (2015-2017)

In the Consumer cyclical sector ROE is substantially stable for listed companies, remaining around 9\% (9.27\% in $2015,9.14 \%$ in 2016 and $8.75 \%$ in 2017); while it shows a growing trend for the unlisted, increasing from $6.78 \%$ to $7.47 \%$ in 2016 and to $21.57 \%$ in 2017.

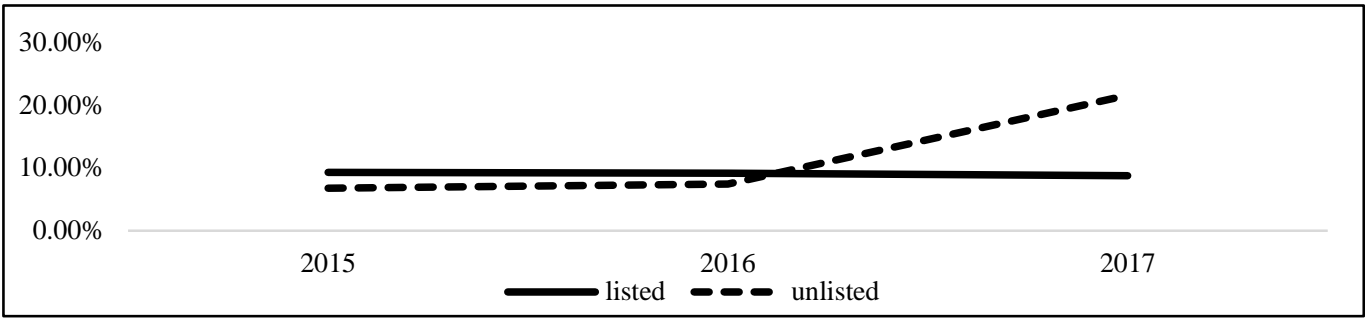

Figure 14. Consumer cyclical: trend ROE (average values) listed vs unlisted companies (2015-2017)

For Consumer non-cyclical the unlisted substantially do not show significant changes in ROE, $(12.40 \%$ in 2015 , $12.50 \%$ in 2016 and $12.42 \%$ in 2017), unlike the listed ones whose ROE grows in 2016 from $1.08 \%$ to $3.24 \%$ and then drop in the following year, assuming the negative value of $-0.81 \%$.

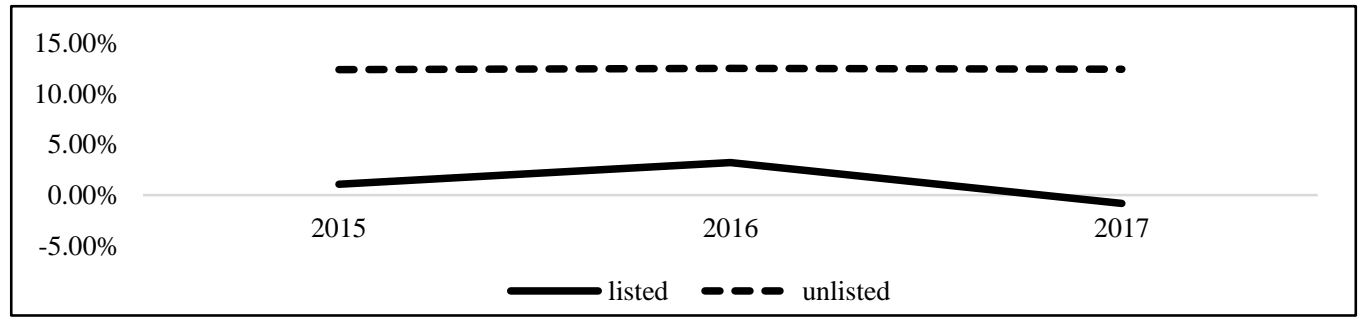

Figure 15. Consumer non cyclical: trend ROE (average values) listed vs unlisted companies (2015-2017) 
For the Energy sector, the ROE in the unlisted decreases in 2016 from $9.97 \%$ to $9.31 \%$, then increase to $10.96 \%$ in 2017; in the listed companies, it increases from $2.07 \%$ in 2015 to $5.03 \%$ and decreases to $0.43 \%$ in the following year, thus highlighting more consistent changes than unlisted companies.

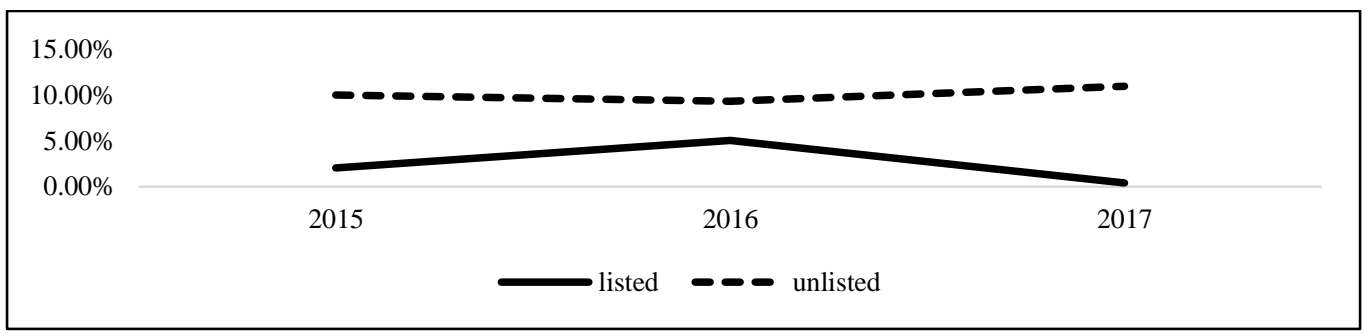

Figure 16. Energy: trend ROE (average values) listed vs unlisted companies (2015-2017)

For the Industrials sector, the ROE trend does not show any significant differences between unlisted and listed companies, remaining substantially unchanged over the three years: in the unlisted sector, in 2016 it went from $14.48 \%$ to $14.80 \%$ and in 2017 to $14,23 \%$; in the listed in 2016 from $9.12 \%$ decreases to $9.03 \%$ in 2016 and increases to $9.13 \%$ in 2017 .

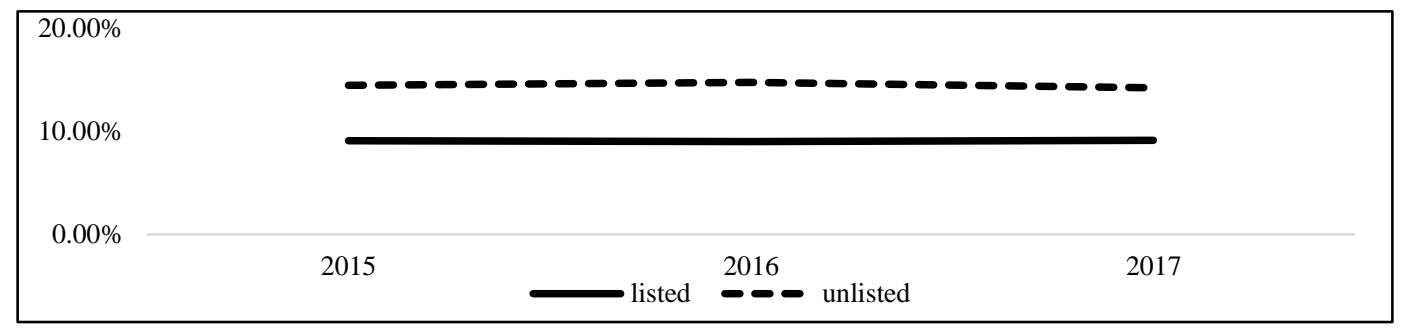

Figure 17. Industrials: trend ROE (average values) listed vs unlisted companies (2015-2017)

In the Basic Materials sector, the ROE for unlisted companies remained practically stable, from $9.41 \%$ in 2015 to $10.02 \%$ in 2016 and $10.16 \%$ in 2017 , while for listed companies it progressively improved from the negative value of $-2.48 \%$ in the first year to the negative value of $-0.04 \%$ in the second year and, finally, $1.68 \%$ in the third year.

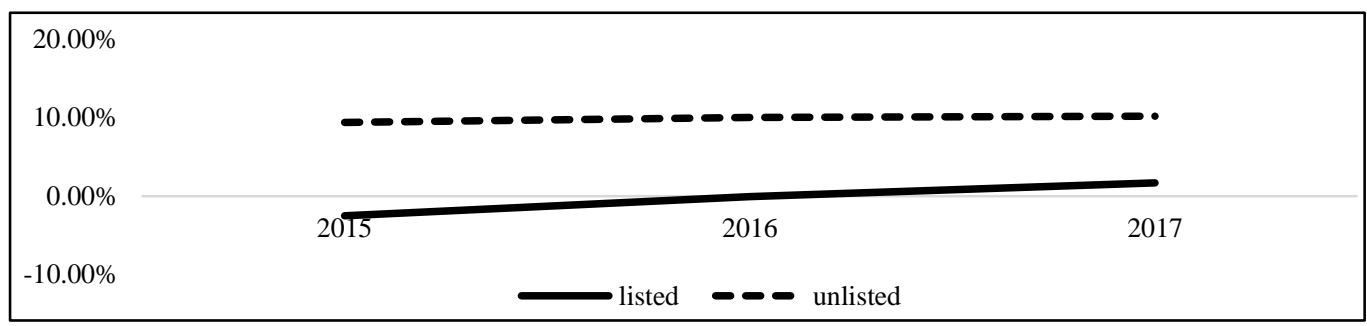

Figure 18. Basic Materials: trend ROE (average values) listed vs unlisted companies (2015-2017)

Also in the Technology sector, the ROE for unlisted companies remained stable $(21.76 \%$ in $2015,21.93 \%$ in 2016 and $21.90 \%$ in 2017), contrary to listed companies in which previously it grew from $7.16 \%$ to ' $8.53 \%$, then it decreases by 5 percentage points, reaching $3.91 \%$.

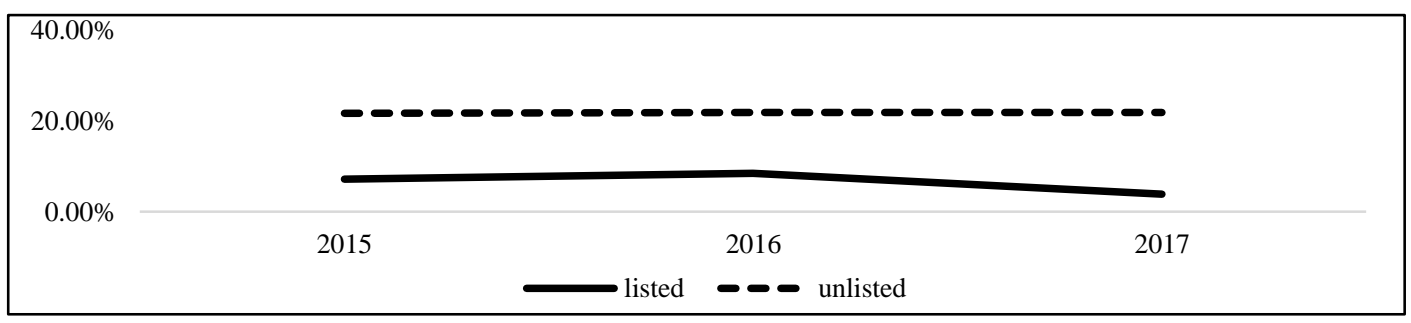

Figure 19. Tecnology: trend ROE (average values) listed vs unlisted companies (2015-2017) 
A similar trend emerges for Telecommunications, considering the ROE which for unlisted companies remains unchanged at more or less $15 \%$ (15.11\% in $2015,15.09 \%$ in 2016 and $15.45 \%$ in 2017), unlike listed company whose ROE in 2016 increased from $3.71 \%$ to $8.71 \%$ and in 2017 decreased to $7.09 \%$.

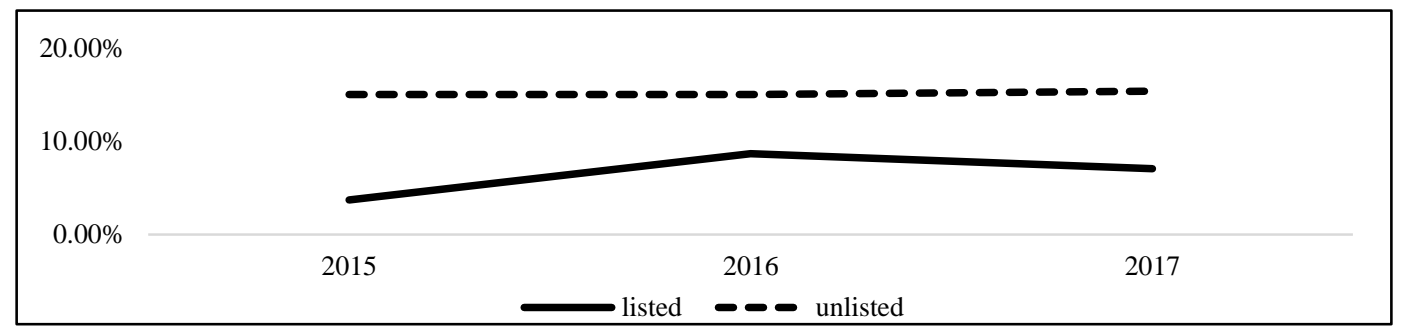

Figure 20. Telecomunications trend ROE (average values) listed vs unlisted companies (2015-2017)

In the Utility sector, the profitability trend in the three years is positive in both panels, however with more marked variations, also in this case, in the unlisted companies: the ROE in the unlisted companies from $7.19 \%$ in 2015 goes to $9.54 \%$ in 2016 and $9.55 \%$ in 2017 as opposed to listed companies which from $-1.22 \%$ in 2015 improve to $7.07 \%$ in 2016 and then reach $7.22 \%$ in 2017.

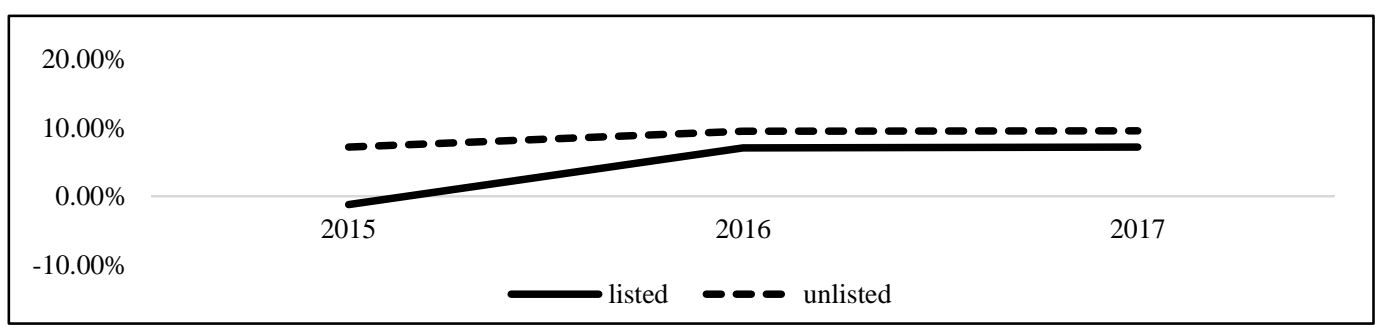

Figure 21. Utility: trend ROE (average values) listed vs unlisted companies (2015-2017)

In short, seven of the nine sectors considered in the study show more marked changes in ROE in listed than in unlisted companies, which instead are characterized by substantial stability. We cannot ignore all this when we want to estimate, as in this work, the effect on the value determined by the going public. The variability of profitability represents, in fact, an element of worsening of the risk profile of the company and, therefore, also of the value for the shareholders.

In light of these results, the survey not only confirms the conclusions contained in other empirical evidence, for which the listing negatively affects the performance of the company (Capasso et al., 2005; Mikkelson et al., 2007), but also introduces an additional element of knowledge represented by the greater variability of the profitability of listed companies.

\subsection{Differential Analysis of Value (ROE- $\left.k_{e}\right)$}

Then, the difference (ROE-ke) was determined for each listed and unlisted company, as a measure of the value for the shareholders. Consistently with the methodology adopted for ROE, the averages of (ROE-ke) were reconstructed, by sector, year and by status listed/unlisted. Results are summarized in the following table.

Table 6. ROE- $\mathrm{k}_{\mathrm{e}}$ (average values): listed vs unlisted

\begin{tabular}{lcccccccc}
\hline \multirow{2}{*}{ Sectors } & \multicolumn{2}{c}{$\mathbf{2 0 1 5}$} & \multicolumn{2}{c}{$\mathbf{2 0 1 6}$} & \multicolumn{2}{c}{$\mathbf{2 0 1 7}$} & \multicolumn{2}{c}{$\mathbf{2 0 1 5 - 2 0 1 7}$} \\
\cline { 2 - 9 } & Listed & Unlisted & Listed & Unlisted & Listed & Unlisted & Listed & Unlisted \\
\hline Health care & $-16.65 \%$ & $4.01 \%$ & $-2.03 \%$ & $3.93 \%$ & $-5.10 \%$ & $3.83 \%$ & $-8.45 \%$ & $3.92 \%$ \\
Consumer cyclical & $1.13 \%$ & $-2.79 \%$ & $1.43 \%$ & $-2.94 \%$ & $0.58 \%$ & $11.51 \%$ & $1.05 \%$ & $1.78 \%$ \\
Consumer non-cyclical & $-5.68 \%$ & $3.84 \%$ & $-3.26 \%$ & $4.26 \%$ & $-8.23 \%$ & $2.82 \%$ & $-5.72 \%$ & $3.64 \%$ \\
Energy & $-6.78 \%$ & $-1.54 \%$ & $-1.64 \%$ & $0.46 \%$ & $-7.15 \%$ & $1.62 \%$ & $-5.28 \%$ & $0.17 \%$ \\
Industrials & $1.41 \%$ & $5.69 \%$ & $1.36 \%$ & $6.09 \%$ & $1.56 \%$ & $5.80 \%$ & $1.44 \%$ & $5.86 \%$ \\
Basic Materials & $-10.00 \%$ & $-0.76 \%$ & $-7.35 \%$ & $0.14 \%$ & $-6.02 \%$ & $-0.18 \%$ & $-7.75 \%$ & $-0.27 \%$ \\
Technology & $0.53 \%$ & $13.11 \%$ & $1.80 \%$ & $13.53 \%$ & $-3.63 \%$ & $12.38 \%$ & $-0.59 \%$ & $12.99 \%$ \\
Telecommunications & $-2.73 \%$ & $8.66 \%$ & $2.51 \%$ & $8.39 \%$ & $-0.04 \%$ & $7.70 \%$ & $-0.02 \%$ & $8.25 \%$ \\
Utility & $-7.33 \%$ & $1.32 \%$ & $0.84 \%$ & $3.61 \%$ & $0.67 \%$ & $2.39 \%$ & $-2.17 \%$ & $2.51 \%$ \\
\hline
\end{tabular}


For the entire 2015-2017 period, the listed companies with the highest values belong to the Industrials (1.44\%), Consumer cyclical $(1.05 \%)$ and Telecommunications $(-0.02 \%)$ sectors; those with the lowest values are in the Healthcare (-8.45\%), Basic Materials (-7.75\%) and Consumer non-cyclical (-5.72\%) sectors.

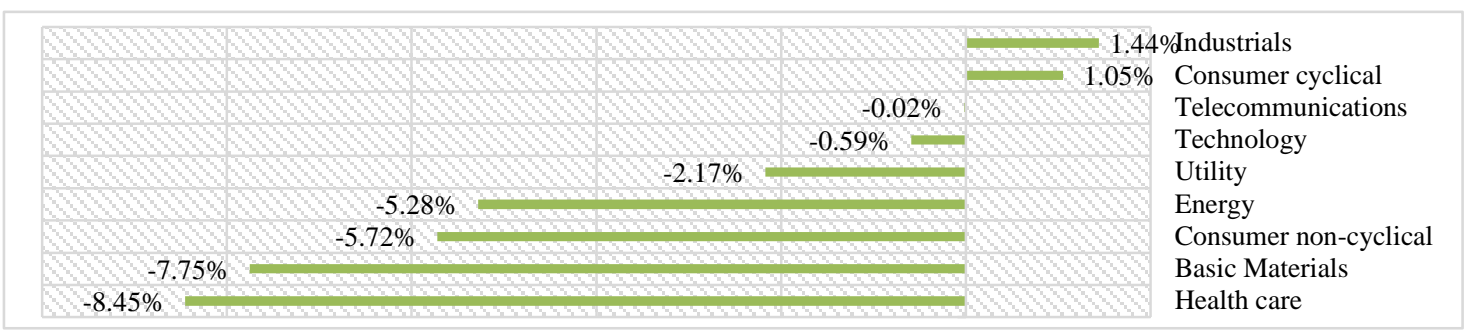

Figure 22. ROE-Ke (average values): ranking listed companies (2015-2017)

In contrast, the unlisted companies with the best values belong to the Technology (12.99\%), Telecommunications $(8.25 \%)$ and Industrials (5.86\%) sectors; those with the worst values correspond to the Basic Materials (-0.27\%), Energy (0.17\%) and Consumer cyclical (1.78\%) sectors.

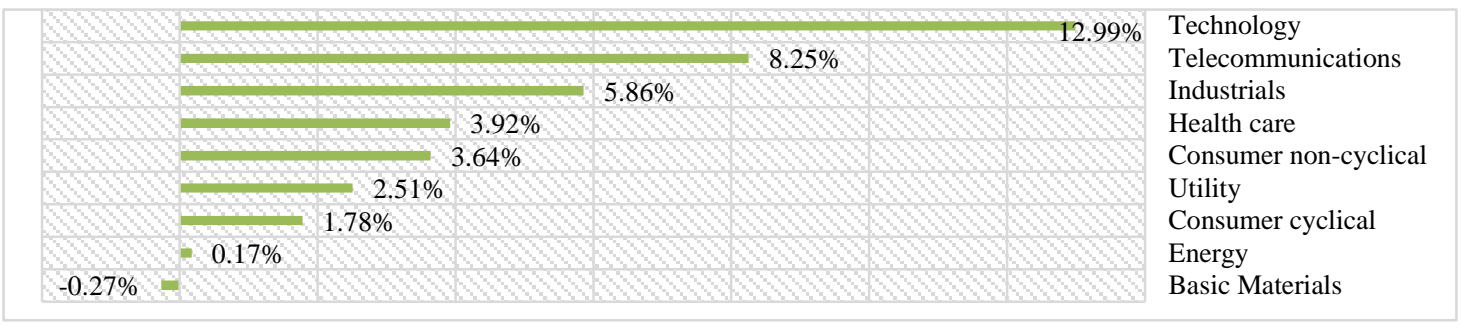

Figure 23. ROE-Ke average values: ranking unlisted companies (2015-2017)

For 2015, it emerges that the most virtuous listed companies, in terms of value creation, are part of the Industrials $(1.41 \%)$, Consumer cyclical $(1.13 \%)$ and Technology $(0.53 \%)$, while the less virtuous ones are in the Utility $(-7.33 \%)$, Basic Materials $(-10.00 \%)$ and Healthcare $(-16.56 \%)$ sectors.

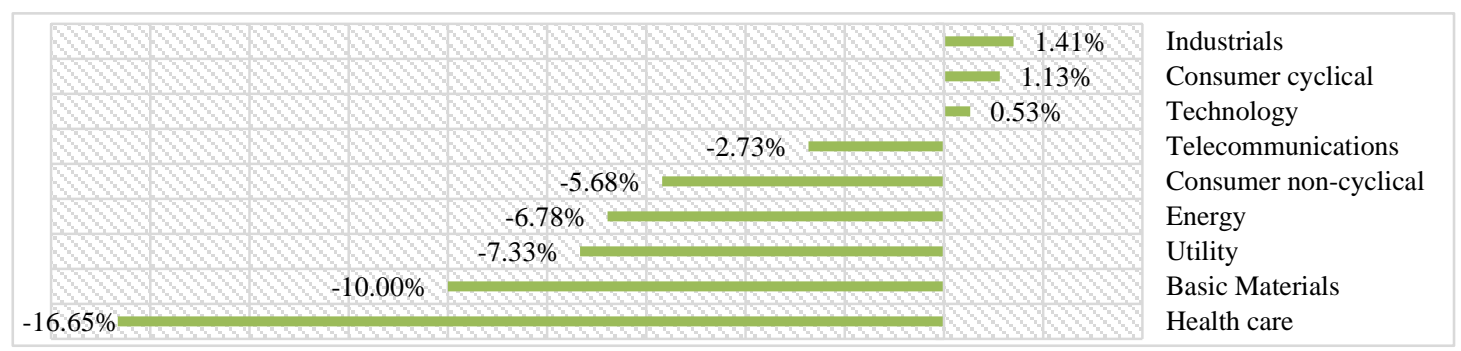

Figure 24. ROE-Ke (average values): ranking listed companies (2015)

With regard to unlisted companies, Technology (13.11\%), Telecommunications $(8.66 \%)$ and Industrials $(5.69 \%)$ are the sectors that show the highest capacity to generate value, while Basic Materials (-0.76 \%), Energy (-1.54\%) and Consumer cyclical $(-2.79 \%)$ show the lowest ability to create value.

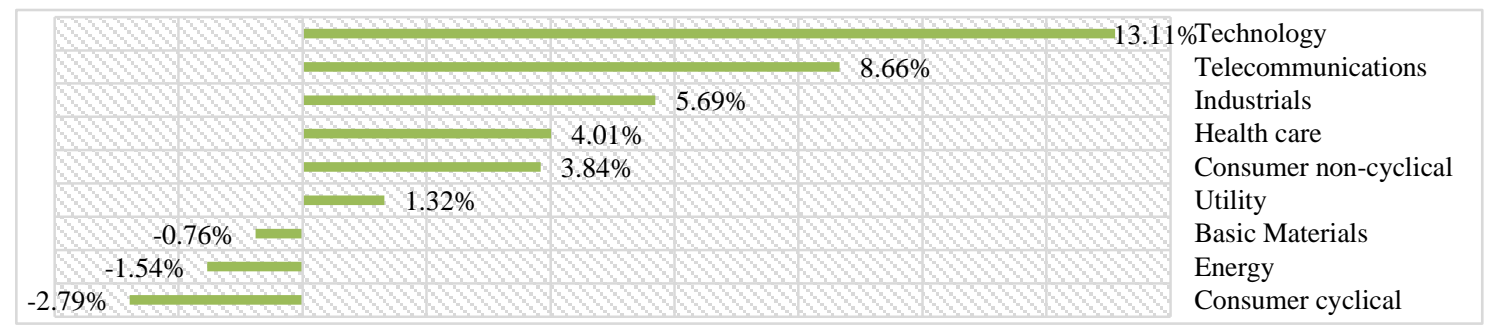

Figure 25. ROE-Ke (average values): ranking unlisted companies (2015) 
Relative to 2016, the best listed companies in terms of value creation for shareholders are in the Telecommunications $(2.51 \%)$, Technology $(1.80 \%)$ and Consumer cyclical $(1.43 \%)$ sectors, while the latter are in the Healthcare (-2.03\%). \%), Consumer non-cyclical (-3.26\%) and Basic materials (-7.35\%) sectors.

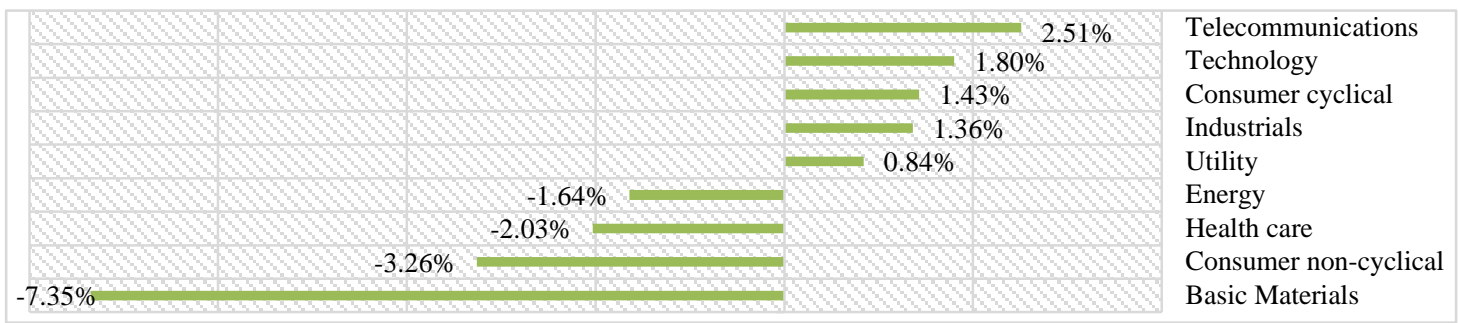

Figure 26. ROE-Ke (average values): ranking listed companies (2016)

Indeed, the unlisted companies with the highest value of (ROE-ke) belong to the Technology (13.53\%), Telecommunications $(8.39 \%)$ and Industrials $(6.09 \%)$ sectors, while those with the lowest value concern the Energy $(0.46 \%)$, Basic Materials $(0.14 \%)$ and Consumer cyclical $(-2.94 \%)$ sectors.

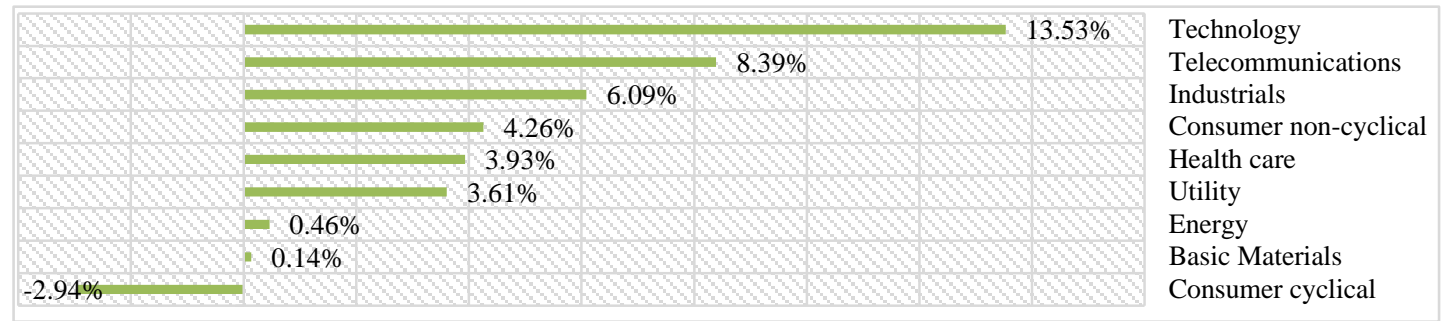

Figure 27. ROE-Ke (average values): ranking unlisted companies (2016)

Lastly, as regards 2017, the listed companies with the best values of (ROE-ke) are in the Industrials (1.56\%), Utility $(0.67 \%)$ and Consumer cyclical $(0.58 \%)$ sectors; those with the worst values are in the Basic Materials (-6.02\%), Energy (-7.15\%) and Consumer non-cyclical (-8.23\%) sectors.

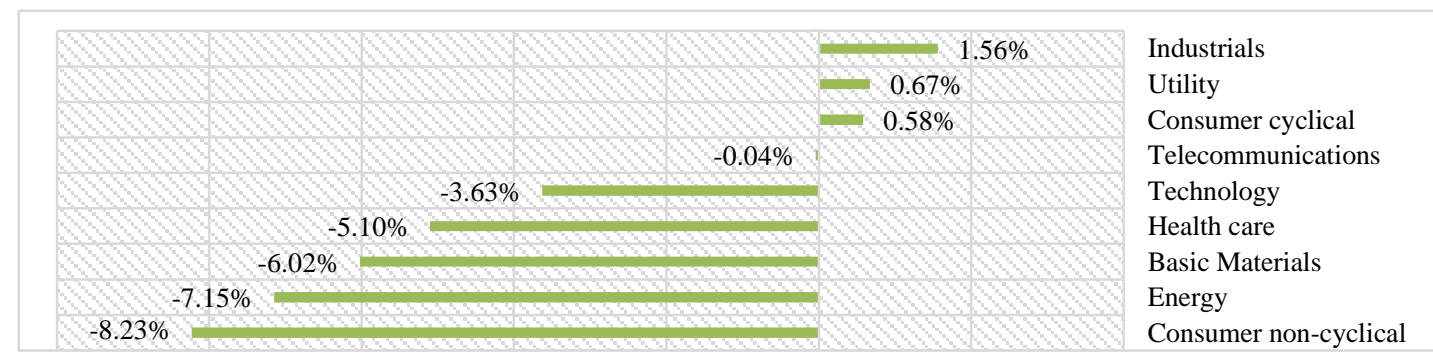

Figure 28. ROE-Ke (average values): ranking listed companies (2017)

Instead, the best unlisted companies are in the Technology (12.38\%), Consumer cyclical $(11.51 \%)$ and Telecommunications (7.70\%) sectors; the worst companies are in the Utility (2.39\%), Energy (1.62\%) and Basic Materials $(-0.18 \%)$ sectors.

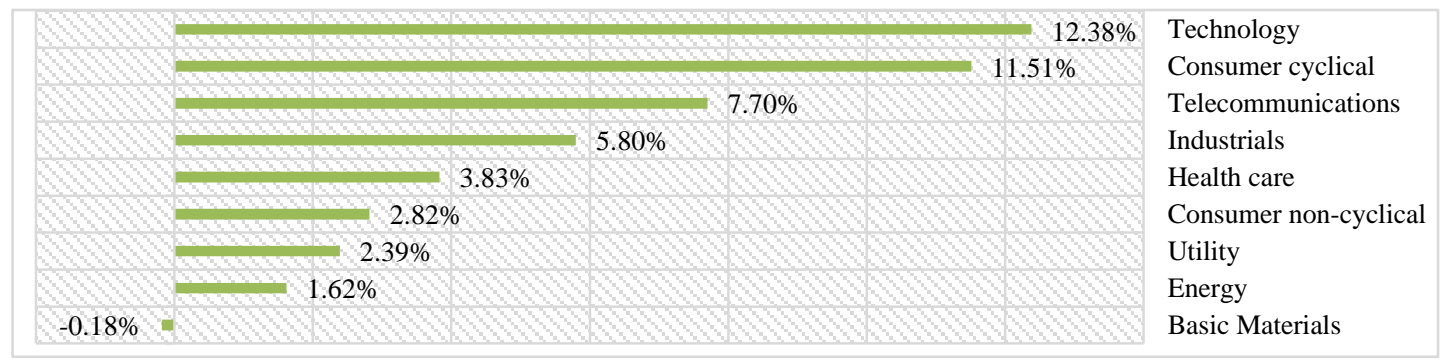

Figure 29. ROE-Ke (average values): ranking unlisted companies (2017) 
The differences in value created by listed companies compared to the unlisted ones provide some elements of knowledge about the importance of the listed/unlisted status. In fact, from the literature there is not a consensus in this regard: some researchers come to the conclusion that the listing harms the generation of value, as it produces more negative than positive effects; others arrive at opposite results, stating that going public facilitates value creation, as it improves the profitability and the accessibility to the financial market.

Considering this, the differences between the means of (ROE-ke) were then calculated and the relative statistical significance was verified using t-test.

Table 7. ROE-k $\mathrm{k}_{\mathrm{e}}$ : differences between the means listed vs unlisted companies (2015-2017)

\begin{tabular}{lcccc}
\hline Sectors & $\mathbf{2 0 1 5}$ & $\mathbf{2 0 1 6}$ & $\mathbf{2 0 1 7}$ & $\mathbf{2 0 1 5 - 2 0 1 7}$ \\
\hline Health care & $-20.66 \% * * *$ & $-5.96 \% * * *$ & $-8.93 \% * * *$ & $-12.37 \% * * *$ \\
& $(0.009)$ & $(0.000)$ & $(0.000)$ & $(0.000)$ \\
Consumer cyclical & $3.92 \% * * *$ & $4.37 \% * * *$ & $-10.93 \% * * *$ & $-0.73 \% * * *$ \\
& $(0.000)$ & $(0.000)$ & $(0.000)$ & $(0.000)$ \\
Consumer non- cyclical & $-9.52 \% * * *$ & $-7.52 \% * * *$ & $-11.05 \% * * *$ & $-9.36 \% * * *$ \\
& $(0.000)$ & $(0.000)$ & $(0.000)$ & $(0.000)$ \\
Energy & $-5.24 \% * * *$ & $-2.10 \%$ & $-8.77 \% * * *$ & $-5.45 \% * * *$ \\
& $(0.000)$ & $(0.453)$ & $(0.004)$ & $(0.000)$ \\
Industrial & $-4.28 \% * * *$ & $-4.73 \% * * *$ & $-4.24 \% * * *$ & $-4.42 \% * * *$ \\
& $(0.000)$ & $(0.000)$ & $(0.000)$ & $(0.000)$ \\
Basic Materials & $-9.24 \% * * *$ & $-7.49 \% * * *$ & $-5.84 \% * * *$ & $-7.48 \% * * *$ \\
& $(0.009)$ & $(0.000)$ & $(0.002)$ & $(0.000)$ \\
Tecnology & $-12.58 \% * * *$ & $-11.73 \% * * *$ & $-16.01 \% * * *$ & $-13.58 \% * * *$ \\
Telecommunications & $(0.000)$ & $(0.000)$ & $(0.002)$ & $(0.000)$ \\
Utility & $-11.39 \% * * *$ & $-5.88 \% * * *$ & $-7.74 \% * * *$ & $-8.27 \% * * *$ \\
& $(0.000)$ & $(0.000)$ & $(0.000)$ & $(0.000)$ \\
\hline
\end{tabular}

Note. Level of significance $* 10 \%, * * 5 \%, * * * 1 \%$.

The t-test highlighted that the averages are comparable for all sectors and for all the years given the level of significance of 1\%, with the exception of the Energy sector limited to 2016.

As regards the entire 2015-2017 period, the difference (ROE-ke) is negative for most of the sectors, demonstrating that listed companies generate less value than unlisted ones, obviously with different intensity between sectors: the greater differences are found in the Technology $(-13.58 \%)$, Healthcare $(-12.37 \%)$ and Consumer non-cyclical (-9.36\%) sectors; the smaller ones are associated with the Consumer cyclical (-0.73\%), Industrials $(-4.42 \%)$ and Utility $(-4.67 \%)$ sectors.

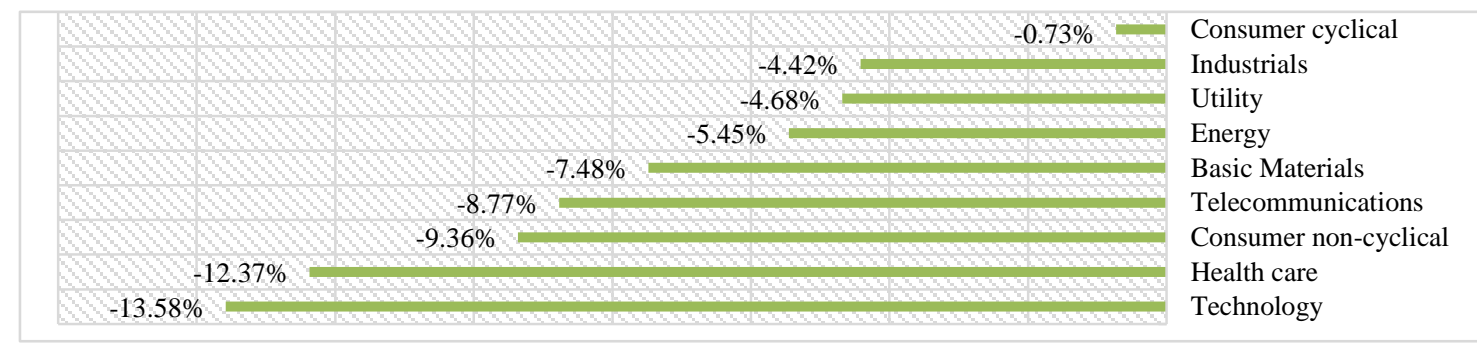

Figure 30. ROE-k $\mathrm{k}_{\mathrm{e}}$ : ranking differences between the means listed vs unlisted companies (2015-2017)

For 2015 the inferiority of listed companies in the creation of value is confirmed for most of the sectors: with the exception of Consumer cyclical, whose (ROE-ke) is equal to $3.92 \%$, the other sectors show a negative value with greater intensity in the Healthcare $(-20.66 \%)$, Technology $(-12.58 \%)$ and Telecommunications $(-11.39 \%)$ sectors. 


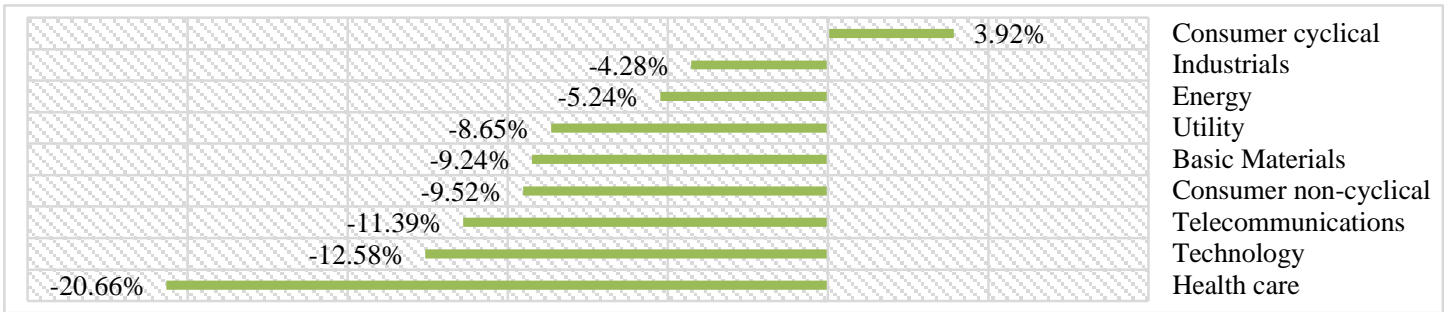

Figura 31. ROE-k $\mathrm{k}_{\mathrm{e}}$ ranking differences between the means listed vs unlisted companies (2015)

For 2016 Consumer cyclical (4.37\%) is the only sector with a difference in favor of listed companies. In the other sectors, the difference (ROE-ke) is always negative: the sectors where this difference is more consistent are Technology (-11.73\%), Consumer non-cyclical (-7.52\%) and Basic materials (-7.49\%).

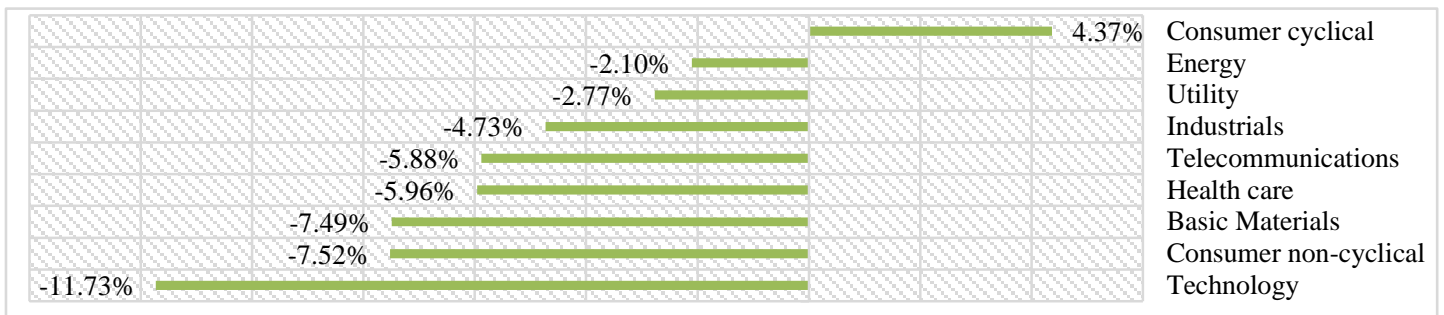

Figure 32. ROE-k $\mathrm{k}_{\mathrm{e}}$ : ranking differences between the means listed vs unlisted companies (2016)

For 2017 all sectors show a negative (ROE-ke) difference and, therefore, a greater ability to create value of unlisted than listed ones. The sectors where this is most evident are Technology (-16.01\%), Consumer non-cyclical $(-11.05 \%)$ and Consumer cyclical (-10.93\%).

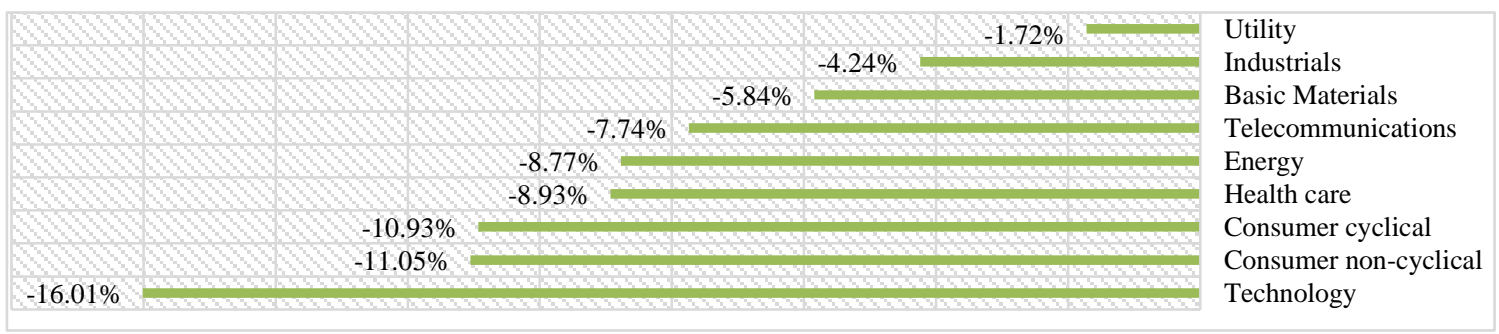

Figure 33. ROE-k $\mathrm{k}_{\mathrm{e}}$ : ranking differences between the means listed vs unlisted companies (2017)

In conclusion, from the analysis of the results of (ROE-ke) it emerges that, with some exceptions, the value created by the unlisted is always higher than that created by the listed.

The trend of the (ROE-ke) is in line with that of the ROE as shown below with reference to the individual sectors.

In particular, in the Healthcare sector the value is positive and remains substantially unchanged at around $4 \%$ in the unlisted $(4.01 \%$ in $2015,3.93 \%$ in 2016 and $3.83 \%$ in 2017), unlike the listed ones in which it remains negative in the three years, improving between $2015(-16.65 \%)$ and $2016(-2.03 \%)$ and falling to $-5.10 \%$ in 2017.

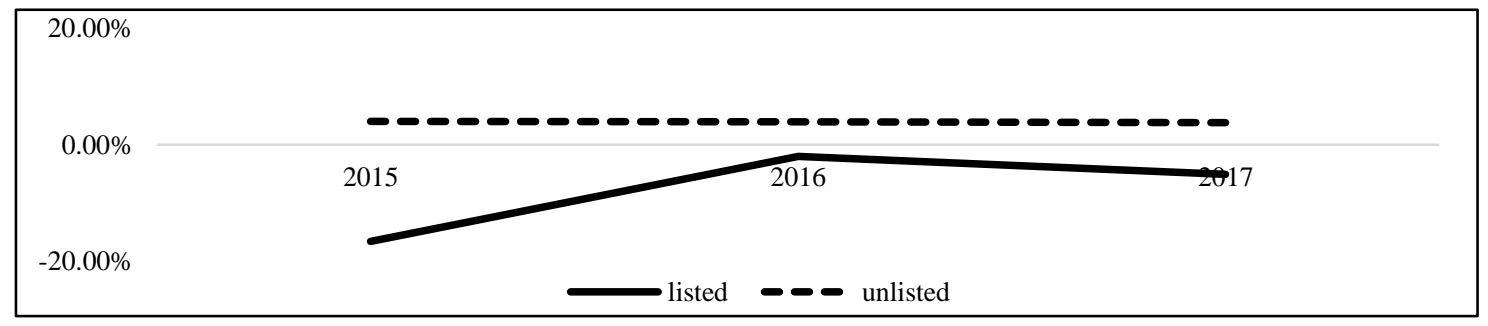

Figure 34. Health care: trend (ROE-k $\mathrm{k}_{\mathrm{e}}$ (average values) listed vs unlisted companies (2015-2017) 
In the Consumer cyclical sector, listed companies generate value in the three years $(1.13 \%$ in $2015,1.43 \%$ in 2016 and $0.58 \%$ in 2017), as opposed to unlisted companies which destroy value in the first two years, given a (ROE-ke) of $-2.79 \%$ in 2015 and $-2.94 \%$ in 2016 , to reach the level of $11.51 \%$ in 2017.

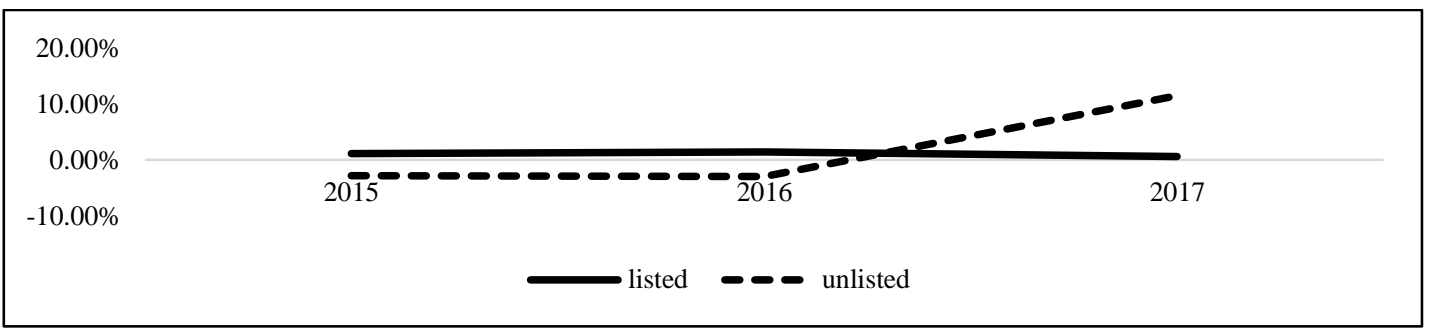

Figure 35. Consumer cyclical: trend (ROE-k $\mathrm{k}_{\mathrm{e}}$ (average values) listed vs unlisted companies (2015-2017)

For Consumer non-cyclical, the value in the unlisted remains positive, from $3.84 \%$ in 2015 to $4.26 \%$ in 2016 and to $2.82 \%$ in 2017 ; while the listed value remains negative, given (ROE-ke) of $-5.68 \%$ in $2015,-3.26 \%$ in 2016 and $-8.23 \%$ in 2017 .

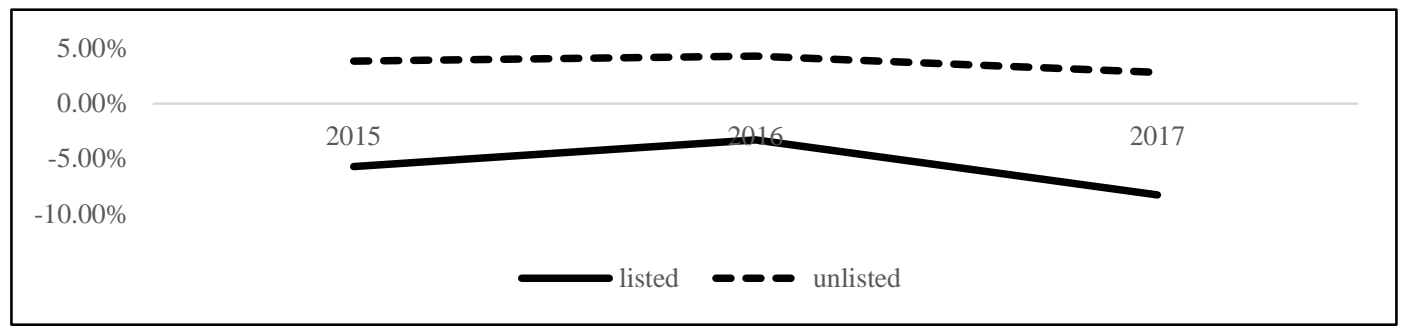

Figure 36. Consumer non cyclical: trend (ROE-k $\mathrm{e}_{\mathrm{e}}$ (average values) listed vs unlisted companies (2015-2017)

For the Energy sector, the value in the unlisted shows a growing trend, increasing both in 2016 and in 2017 , unlike the listed ones which show an increase in $2016(-1.64 \%)$ compared to $2015(-6.78 \%)$ and decrease in 2017 $(-7.15 \%)$.

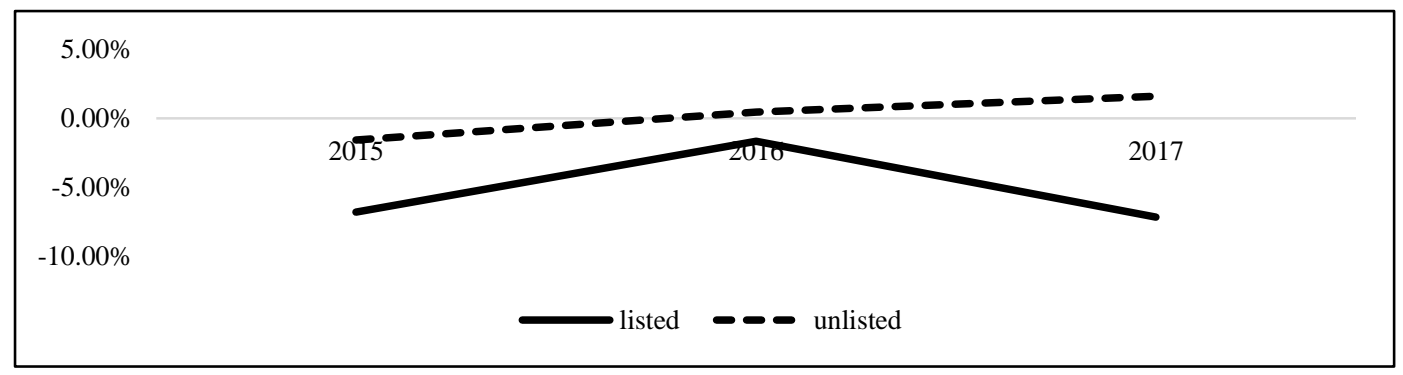

Figure 37. Energy: trend (ROE-k $\mathrm{e}_{\mathrm{e}}$ ) (average values) listed vs unlisted companies (2015-2017)

With reference to the Industrials sector, the trend is almost stable both in the unlisted and in the listed, given the difference (ROE-ke) which in the first remains around 6\% (5.69\% in 2015, 6.09\% in 2016 and 5.80\% in 2017) and in the latter more or less $1.4 \%$ (1.41\% in $2015,1.36 \%$ in 2016 and $1.56 \%$ in 2017).

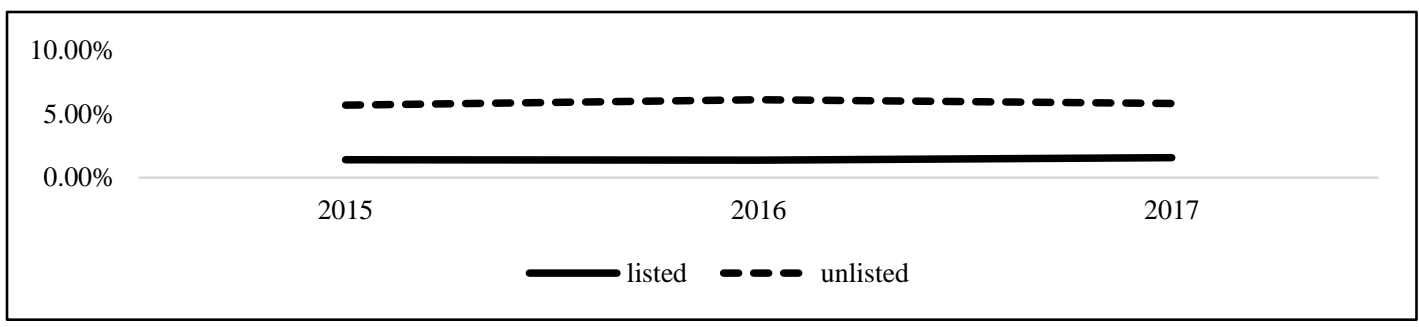

Figure 38. Industrials: trend (ROE-k $\mathrm{k}_{\mathrm{e}}$ (average values) listed vs unlisted companies (2015-2017) 
As regards the Basic Materials sector, the value does not show significant changes in unlisted companies, growing slightly between 2015 and 2016 and falling slightly in 2017, while it shows an upward trend in the listed companies, given a (ROE-ke) of $-10.00 \%$ in $2015,-7.35 \%$ in 2016 and $-6.02 \%$ in 2017.

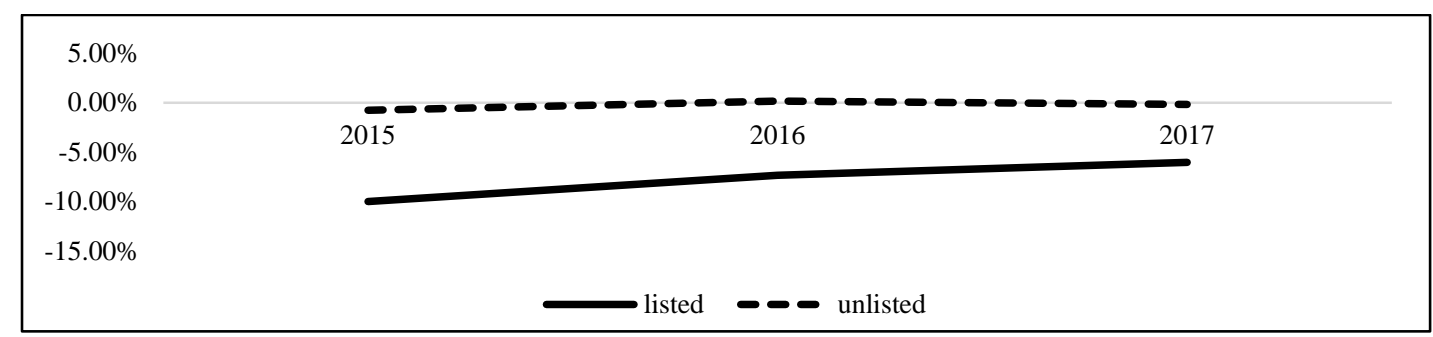

Figure 39. Basic Materials: trend (ROE-ke) (average values) listed vs unlisted companies (2015-2017)

For the Technology sector, the value remains substantially stable in the unlisted, given the (ROE-ke) of $13.11 \%$ in $2015,13.53 \%$ in 2016 and $12.38 \%$ in 2017, unlike the listed ones whose value grew in $2016(1.80 \%)$ and drops in 2017 (-3.63\%).

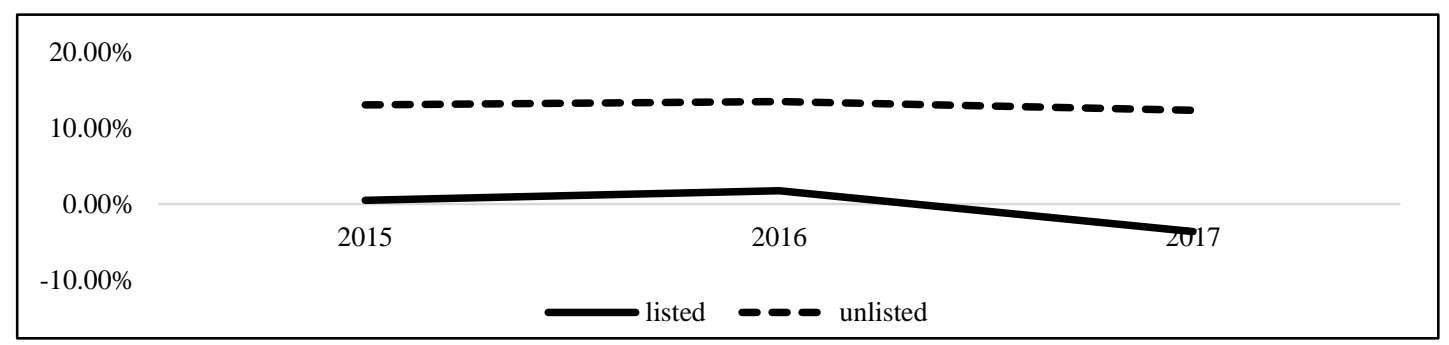

Figure 40. Tecnology: trend (ROE-ke) (average values) listed vs unlisted companies (2015-2017)

With regard to the Telecommunications sector, for the unlisted companies the value remains around $8 \%$ in decrease, (8.66\% in 2015, 8.39\% in 2016 and $7.70 \%$ in 2017); listed companies, on the other hand, show greater variability, growing in 2016 (2.51\%) and falling in 2017 (-0.04\%).

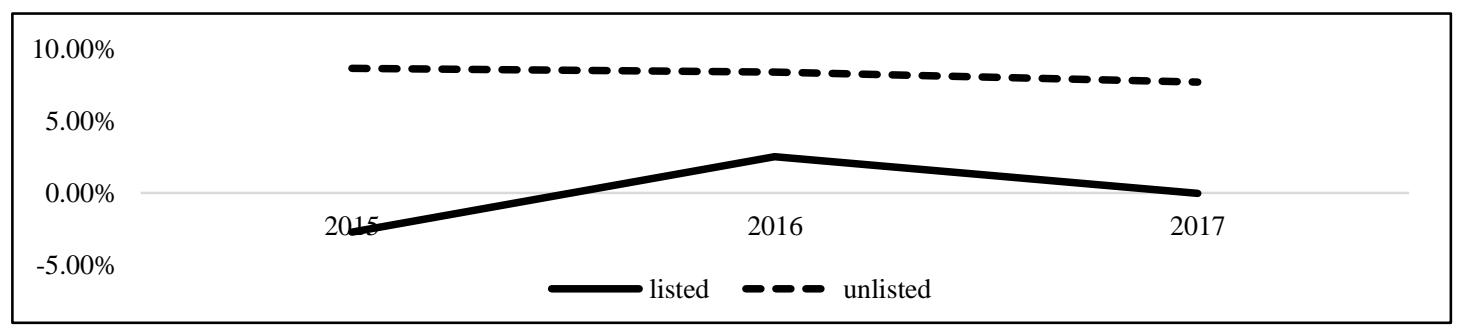

Figure 41. Telecomunications: trend (ROE-ke) (average values) listed vs unlisted companies (2015-2017)

Even in the Utility sector, the unlisted companies have a more stable trend than the listed ones: the former grow in 2016 to $3.61 \%$ from $1.32 \%$ in 2015 and fall $2.39 \%$ in 2017 while the latter grew significantly between 2015 $(-7.33 \%)$ and $2016(0.84 \%)$ and then decreased in $2017(0.67 \%)$.

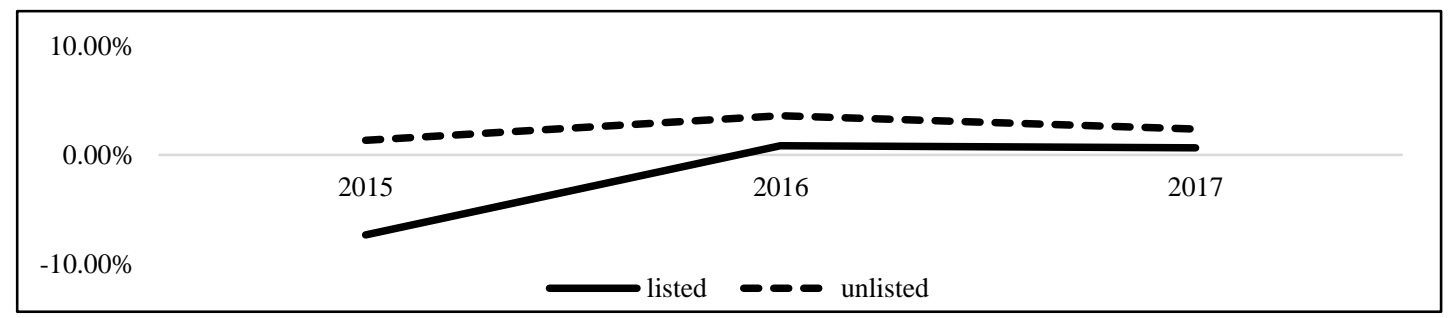

Figure 42. Utility: trend (ROE-ke) (average values) listed vs unlisted companies (2015-2017) 


\section{Conclusions}

In this paper we investigated if listing is able to affect profitability and value creation. This represents one of main factors subject to intense debate in the academic community. Consistently with the shareholders approach, we choosed to measure profitability using the ROE and the value creation with the difference ROE-ke assuming that a positive difference states the capability of a company to create value for shareholders. We compared listed and unlisted companies located in the European countries belonging to the Stoxx Europe 600. Data have been extracted from Amadeus database. Analysis refers to the period 2015-2017. For the whole period of investigation unlisted companies show higher value of ROE and ROE-ke than the listed ones in all sectors. In particular, results show that the profitability of unlisted companies is on average higher than that of listed companies especially in the Technology, Telecommunication and Industrials sectors. For the same sectors, findings highlights also a higher ROE-ke differential of unlisted companies compared to the listed.

Results are influenced by higher value of ROE in the unlisted sample, which attests to a greater return on equity. The difference between the two samples is significant at $1 \%$ significance level for both ROE and ROE-ke and confirm that the effect of the listing in terms of a decrease in the cost of capital is so small that it only minimally compensates for the negative effect on profitability.

Outcomes highlighted in this study confirm those obtained by Rondi et al. (1994), Xiaoying (2010), Akguc, Choi, and Kim (2015) which affirm listed companies are no more performing than unlisted ones.

\section{References}

Abbate, C., \& Sapio, A. (2015). Gazelles in the City: stock market listing and its impact on firm growth quantiles.

Abdallah, A. A., \& Ioannidis, C. (2010). Why do firms cross-list? International Evidence from the US Market. The Quarterly Review of Economics and Finance, 50(2), 202-213. https://doi.org/10.1016/j.qref.2009.09.009

Aiello, F., \& Silipo, D. (1997). Gli effetti del mercato dei capitali sulla performance delle imprese italiane. Quaderni di Economia e Finanza, 6(2), 83-113.

Akguc, S., Choi, J., \& Kim, S. (2015). Do private firms perform better than public firms. Working paper, Temple University, Philadelphia.

Almisher, M. A., \& Kish, R. J., (2000) Accounting Betas - An ex anti Proxy for Risk within IPO Marke. Journal of Financial and Strategic Decisions, 13(3), 23-34.

Ameer, R. (2012). Macroeconomic factors and initial public offerings (IPOs) in Malaysia. Asian Academy of Management Journal of Accounting and Finance, 8(1), 41-67.

Bancel, F., \& Mittoo, U. R. (2014). The Gap between Theory and Practice of Firm Valuation: Survey of European Valuation Experts. https://doi.org/10.1111/jacf.12095

Bates, J., \& Hally, D. L. (1982). The Financing of Small Business (3rd ed.). London, Sweet \& Maxwell.

Berkman, H. (2013). The capital asset pricing model: A revolutionary idea in finance. Abacus. https://doi.org/10.1111/j.1467-6281.2012.00381.x

Brau, J. C., \& Fawcett, S. E. (2006). Initial public offerings: An analysis of theory and practice. The Journal of Finance, 61(1), 399-436. https://doi.org/10.1111/j.1540-6261.2006.00840.x

Bruner, R., Eades, K., Harris, R., \& Higgins, R. (1998). Best Practices in Estimating the Cost of Capital: Survey and Synthesis. Financial Practice and Education, 8(1), 13-28.

Capasso, A., Rossi, M., \& Simonetti, B. (2005). Ownership Structure Heterogeneity and Performance: A Comparison between Listed and Unlisted Companies. SSRN Electronic Journal. https://doi.org/10.2139/SSRN.890624

Caselli S. (2003). PMI e sistema finanziario. Comportamento delle imprese e strategia delle banche. Egea.

Corigliano R. (2001). Il venture capital. Finanziamento dell'innovazione, capitale di rischio e nuovi mercati finanziari. Bancaria Editrice.

Ellingsen, T., \& Rydqvist, K. (1997). The Stock Market as a Screening Device and the Decision to Go Public. Working Paper in Economics and Finance, p. 174. https://doi.org/10.2139/ssrn.75358

Global IPO Institutional Investor survey. (2009). 
Hamid, N. (2004). Role of Capital Markets in Investment Banking Development. A Speech Presented at ADB; ADB Website.

Hutchinson, P. J., \& Ray, G. H. (1983). The Financing and Financial Control of Small Enterprise Development. Gower Publishing Company Limited, England.

Keown, A. J., Scott, Jr. D. F., Martin, J. D., \& Petty J. W. (1985). Basic Financial Management (3rd ed.). Prentice Hall International Editions, New Jersey.

Mayer, C. P., \& Alexander, I. (1991). Stock Markets and Corporate Performance: A Comparison of Quoted and Unquoted Companies. Discussion Paper N. 571, CEPR, London.

McLaney, E. (2009). Business Finance: Theory and Practice (8th ed.). Prentice Hall, United Kingdom.

Meluzin, T., \& Zinecker, M. (2014). Reasons for IPO Implementation: Empirical Evidence from the Polish Capital Market. Engineering Economics, 25(3), 294-301. https://doi.org/10.5755/J01.EE.25.3.3529

Mikkelson, W. J., Partch, M. M., \& Shan, K. (1997). Ownership and operating performance of companies that go public. Journal of Financial Economics, 44(3), 281-307. https://doi.org/10.1016/S0304-405X(97)00006-8

Pagano, M., Panetta, F., \& Zingales, L. (1996). Why Do Companies Go Public? An Empirical Analysis. In Pagano, M., \& Roell, A. (Eds.), The decision to go public and the stock market as a source of capital, Bancaria Editrice, Roma. https://doi.org/10.3386/w5367

Pagano, M., Panetta, F., \& Zingales, L. (1998). Why Do Companies Go Public? An Empirical Analysis. The Journal of Finance, 53(1), 27-64. https://doi.org/10.1111/0022-1082.25448

Romano, G. (2012). Strategie aziendali e quotazione in Borsa. Giuffrè Editore.

Rondi, L., Sembenelli, A., \& Zanetti, G. (1994). Is Excess Sensitivity of Investment to FinancialFactors Constant across Firms? Evidence from Panel Data on Italian Companies. Journal of Empirical Finance, 1, 365-383. https://doi.org/10.1016/0927-5398(94)90009-4

Van Tan, N., \& Quoc, T. T. (2019). Listing and Firm Performance in a Transition Economy. Asian Economic and Financial Review, 9(3), 353-365. https://doi.org/10.18488/journal.aefr.2019.93.353.365

Xiaoying, X. (2010). Are publicly held firms less efficient? Evidence from the US property-liability insurance industry. Journal of Banking \& Finance, 34(7), 1549-1563. https://doi.org/10.1016/j.jbankfin.2010.01.007

Zamagni, S. (2006). Responsabilità sociale delle imprese e democratic stakeholding. Università di Bologna sede di Forlì, Working Paper, 28.

\section{Notes}

Note 1. Value Trust Analisysof cost of capital parameters for European capital market.

Note 2. The Residual Income Valuation Model allows to determine

$$
k_{e_{l_{s}}}=\frac{R N_{t+1}}{C M_{t}}+\left(1-\frac{V C_{t}}{C M_{t}}\right) \times g
$$

where:

- $k_{e_{l_{s}}}$ sector equity levered cost;

- $R N_{t+1}$ net income at $t+1$;

- $C M_{t}$ market capitalization at time $t$;

- $V C_{t}$ accounting value at time $t$;

- $g$ rate of growt.

\section{Copyrights}

Copyright for this article is retained by the author(s), with first publication rights granted to the journal.

This is an open-access article distributed under the terms and conditions of the Creative Commons Attribution license (http://creativecommons.org/licenses/by/4.0/). 